\title{
Ferroptosis in Neurons and Cancer Cells Is Similar But Differentially Regulated by Histone Deacetylase Inhibitors
}

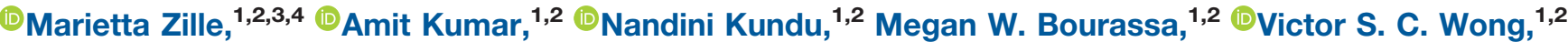 \\ (-Dianna Willis, ${ }^{1,2}$ - Saravanan S. Karuppagounder, ${ }^{1,2}$ and ${ }^{-}$Rajiv R. Ratan ${ }^{1,2}$
}

https://doi.org/10.1523/ENEURO.0263-18.2019

${ }^{1}$ Burke Neurological Institute, White Plains, New York 10605, ${ }^{2}$ Feil Family Brain and Mind Research Institute, Weill Cornell Medicine, New York, New York 10065, ${ }^{3}$ Fraunhofer Research Institution for Marine Biotechnology and Cell Technology and Institute for Medical and Marine Biotechnology, University of Lübeck, Lübeck, 23562, Germany,

${ }^{4}$ Institute for Experimental and Clinical Pharmacology and Toxicology, University of Lübeck, Lübeck, 23562, Germany

\section{Visual Abstract}

\section{Cancer Cells}

Erastin / Glutamate / Homocysteate
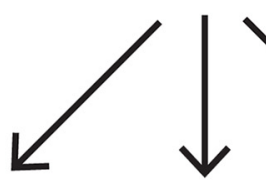

Ferroptosis

Necroptosis

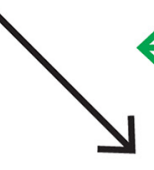

Autophagy

\section{Neurons}

Erastin / Glutamate / Homocysteate

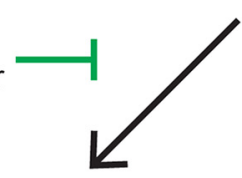

Ferroptosis

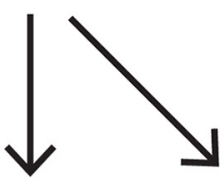

Necroptosis Autophagy
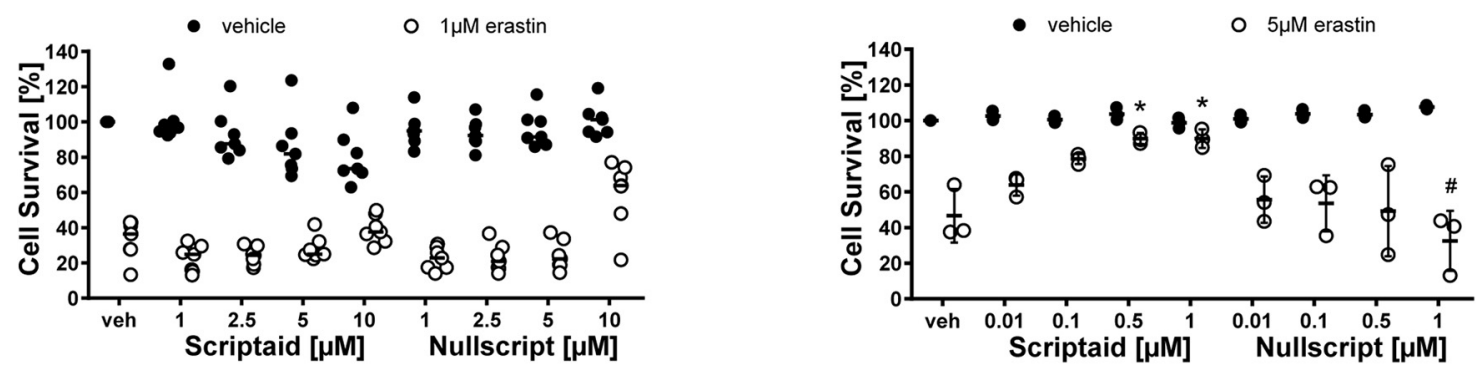

\section{Significance Statement}

A major challenge in cancer chemotherapy is to effectively kill tumor cells while preserving healthy tissue. The nervous system is particularly vulnerable to side effects by anti-cancer agents. Agents that induce a recently identified type of cell death, called ferroptosis, are widely being considered for cancer treatment. However, precise understanding of how ferroptosis induction in cancer cells may simultaneously thwart function or viability of post-mitotic neurons is essential in defining the efficacy and toxicity of these agents. We show that mechanisms of ferroptotic cell death in cancer cells are similar to those in neurons. We leverage prior studies of ferroptosis in neurons to identify histone deacetylase inhibitors as agents that enhance chemotherapy-induced ferroptosis of tumors while inhibiting ferroptosis in neurons. 
Ferroptotic death is a mechanism for tumor suppression by pharmacological inhibitors that target the $\mathrm{X}_{\mathrm{c}}{ }^{-}$ transporter (cystine/glutamate antiporter) in a host of non-CNS and CNS tumors. Inhibition of this transporter leads to reduction of cystine uptake, cyst(e)ine deprivation, subsequent depletion of the versatile antioxidant glutathione, and reactive lipid species-dependent death. Accordingly, pharmacological inhibitors of the $X_{c}{ }^{-}$ transporter can also induce neuronal cell death raising concerns about toxicity in the CNS and PNS if these agents are used for chemotherapy. Here, we show that ferroptotic death induced by the canonical ferroptosis inducer erastin is similar in HT1080 fibrosarcoma cells and primary cortical neurons although cell death is mediated more potently in cancer cells. Reducing the toxicity of ferroptosis inducers will require, among other things, the identification of agents that protect neurons from ferroptosis but exacerbate it in tumor cells. Although we show that a number of agents known to block ferroptosis in primary mouse neurons also inhibit ferroptosis in fibrosarcoma cells, class I histone deacetylase (HDAC) inhibitors selectively protect neurons while augmenting ferroptosis in cancer cells. Our results further suggest that cell death pathways induced by erastin in these two cell types are statistically identical to each other and identical to oxidative glutamate toxicity in neurons, where death is also mediated via inhibition of $\mathrm{X}_{\mathrm{c}}{ }^{-}$cystine transport. Together, these studies identify HDACs inhibitors as a novel class of agents to augment tumor suppression by ferroptosis induction and to minimize neuronal toxicity that could manifest as peripheral neuropathy or chemo brain.

Key words: apoptosis; cell death; chemotherapy; ferroptosis; necroptosis; necrosis

\section{Introduction}

Cancer is among the leading causes of death worldwide, and its incidence is expected to increase within the next decades. Accordingly, there are intense efforts to develop novel small molecules that can induce death of cancer cells. In an attempt to target tumor cells with activating mutations of RAS, which are present in around a third of all cancers, Dixon et al. (2012) identified the small molecule chemotherapeutic agent erastin. The authors characterized the mechanisms of erastin-induced death and found that cells die in an iron-dependent form of non-apoptotic cell death they called ferroptosis. They further showed that erastin induces ferroptosis by selectively inhibiting the plasma membrane transport of cyst(e)ine via a well-characterized cystine/glutamate exchanger $\left(\mathrm{X}_{\mathrm{C}}{ }^{-}\right)$. Cyst(e)ine depletion leads to decreased levels of glutathione (Bridges et al., 2012; Lewerenz et al., 2013), culminating in cell death due to the production of

Received June 28, 2018; accepted January 18, 2019; First published January 31, 2019.

The authors declare no competing financial interests.

Author contributions: M.Z. and R.R.R. designed all experiments; M.Z. performed all experiments except Scriptaid experiments in erastin-induced cell death in PCN, which were performed by M.W.B., SH-SY5Y and Hep3B experiments, which were performed by A.K., DRG experiments, which were performed by V.S.C.W. and D.W., and gene expression experiments, which were performed by S.S.K. and N.K.; M.Z. analyzed the data, performed the statistical analysis, and graphical artwork; M.Z. and R.R.R. wrote and edited the paper; all authors discussed the results and commented on the paper.

This work was supported by Grant DFG Zi 1613/1-1 (Project \#298966395) to M.Z. from the German Research Foundation, and funding from the Sheldon G. and Dr. Miriam Adelson Medical Research Foundation and the Sperling Center for Hemorrhagic Stroke Recovery to R.R.R. The rabbit anti-phospho-S166 RIP1 antibody was provided by Peter J. Gough, John Bertin, and Joshua Finger, (GlaxoSmithKline).

Correspondence should be addressed to Rajiv R. Ratan at rrr2001@med.cornell.edu.

https://doi.org/10.1523/ENEURO.0263-18.2019

Copyright (C) 2019 Zille et al.

This is an open-access article distributed under the terms of the Creative Commons Attribution 4.0 International license, which permits unrestricted use, distribution and reproduction in any medium provided that the original work is properly attributed. reactive lipid species (Tan et al., 1998; Yang and Stockwell, 2016).

A major challenge in effective cancer chemotherapy is to reduce side effects on the central nervous system (e.g., chemo brain-deficits in cognitive function, memory, and attention) or peripheral nervous system (e.g., neuropathic pain) toxicities (Banach et al., 2017; Vitali et al., 2017). These toxicities can reduce the quality of life and functional status even in circumstances where chemotherapy effectively neutralizes the tumor (Kerckhove et al., 2017).

To understand the potential toxicities of erastin in CNS neurons, we here examine the signaling pathways engaged by erastin in post-mitotic cortical neurons and compare them to those activated in HT1080 fibrosarcoma cells.

\section{Materials and Methods}

\section{Chemicals and reagents}

Apicidin (catalog \#10575), DPQ (14450), and Nullscript (16433) were obtained from Cayman Chemical. 3-Methyladenine (BML-AP502-0025), Mdivi-1 (BML-CM127-0010), Necrostatin-1 (BML-AP309-0020), Scriptaid (BML-GR326-0005), Trolox (ALX-270-267-M100), and z-VAD-fmk (ALX-260-138R100) were purchased from Enzo Life Sciences. Bafilomycin A1 $\left(B_{1080}\right)$, cyclosporine A (C-6000), Olaparib (O-9201), SB203580 (S-3400), SP600125 (S-7979), and U0126 (U-6770) were obtained from LC Laboratories. Laminin (CC095), GSK'872 (530389), Necrostatin-1 inactive (480066), Necrosulfonamide (480073) mouse tumor necrosis factor- $\alpha$ (GF027), U0124 (662006), and rabbit anti-acetylated Histone H4 (1:5000; 06-866; RRID:AB_310270) antibody were from Millipore; BocDON-Gln-lle-Val-OMe (B003), 1,3-dimethyl-4,5-diphenyl-2-[(2oxopropyl)thio]imidazolium trifluorosulfonic acid salt (D004) from Zedira $\mathrm{GmbH}$; 3-(4,5-dimethylthiazol-2-yl)-2,5diphenyltetrazolium bromide (MTT assay, G4100) from Promega; erastin (S7242) and entinostat (MS-275, S1053) from Selleck Chemicals. Actinomycin D (A1410), Chloroquine (C6628), cycloheximide (01810), Cystamine dihydrochloride (C8707), Deferoxamine (D9533), Ferrostatin-1 (SML0583), Homocysteate (H9633), Mithramycin A (M6891), N-acetylcysteine 
(A7250), rapamycin (R8781), sodium butyrate (303410), protease inhibitor cocktail (P8340), poly-D-lysine (P6407), poly-Llysine (P4704), N1 supplement (N6530), collagenase (C9697), EGTA (E0396), sodium orthovanadate (S6508), mouse anti- $\beta$ actin (1:20,000; clone AC-74, A5316; RRID:AB_476743), and Tween 20 (P7949) were obtained from Sigma-Aldrich. EDTA (E177) was obtained from Amresco. Triton X-100 (161-0407), DC Protein Assay Kit I (5000111), Quick Start Bradford Reagent (500-0205), and Protein Dual Color Standard (161-0374) were purchased from Bio-Rad. DMEM (11965118), DMEM/nutrient mixture F-12 (10565-018), MEM GlutaMAX Supplement (41090101), MEM non-essential amino acids (11140050), fetal bovine serum (16140071), horse serum (26050088), penicillinstreptomycin (15140163), live/dead assay (L3224), NuPAGE $4 \%$ and $12 \%$ Bis-Tris protein gels (NP0335 and NP0336), MES SDS Running Buffer (NP0002), TaqMan c-Myc (Hs00153408), p21 (Hs00355782), HDAC1 (Hs00606262_g1), HDAC2 (Hs00231032_m1), HDAC3 (Hs00187320_m1), HDAC8 (Hs00954353_g1), GAPDH (4332649) human primers, HDAC1 (Mm02391771), HDAC2 (Mm00515108), HDAC3 (Mm00515916), HDAC8 (Mm01224980_m1) mouse primers, mouse $\beta$-actin endogenous control VIC (4352341E), TaqMan RNA-to-CT 1-Step Kit (4392656), and MicroAmp 96-well Reaction Plates (4346906) were purchased from ThermoFisher Scientific. Laemmli SDS Sample Buffer (BP-110R), Transfer Buffer (BP-190), and Tris-Buffered Saline (BM-300) were obtained from Boston BioProducts. Methanol (BDH1135) was purchased from WWR. Mouse anti-Histone H4 (1:5000; 2960S; RRID:AB_1147657) antibody was from Cell Signaling Technology. Rabbit anti-phospho-S166 RIP1 antibody (1:2000) was provided by P.J.G., J.B., and J.F. (GlaxoSmithKline). Nitrocellulose membrane $0.2 \mu \mathrm{m}$ (10600001) was from GE Healthcare. Odyssey Blocking Buffer (927-40010), goat anti-rabbit 680RD (1:20,000, 926-68071; RRID:AB_10956166), and goat antimouse 800CW (1:20,000; 926-32210; RRID:AB_621842) were purchased from LI-COR Biosciences. NucleoSpin RNA isolation kit (740955) was obtained from Clontech. Eagle's Minimum Essential Medium (30-2003) was from American type Culture Collection.

3-Methyladenine, actinomycin D, Apicidin, Bafilomycin A1, B003, Cycloheximide, ayclosporine A, D004, DPQ, erastin, ferrostatin-1, Mdivi-1, Mithramycin A, MS-275, Necrostatin-1, Necrostatin-1 inactive, Nullscript, Olaparib, rapamycin, SB203580, Scriptaid, SP600125, U0124, U0126, and z-VAD-fmk were dissolved in DMSO. Chloroquine, Cystamine dihydrochloride, Deferoxamine, and $\mathrm{N}$-acetylcysteine were dissolved in water, Tumor necrosis factor- $\alpha$ in PBS, and Trolox in ethanol. Homocysteate was dissolved in MEM and further diluted in water to $250 \mathrm{mM}$ stock solution. Sodium butyrate was dissolved in culture media.

\section{Animals}

All animal procedures were approved by the Weill Cornell Medicine Institutional Animal Care and Use Committee (Approval \#0707-633A) and conducted in accordance with the NIH Guide for the Care and Use of Laboratory Animals and ARRIVE guidelines. Mice were purchased from Charles River Laboratories and housed at $20-22^{\circ} \mathrm{C}$,
30-70\% humidity, under a $12 \mathrm{~h}$ light/dark cycle, with food (PicoLab Rodent diet 5053, LabDiet) and water ad libitum.

\section{Cell culture}

Primary cortical neurons were obtained from CD-1/ICR mice of either sex at embryonic day 14.5. Briefly, cortices were dissected, homogenized, and plated in poly-Dlysine-coated plates in minimum essential medium containing $10 \%$ fetal bovine serum, $5 \%$ horse serum, and $1 \%$ penicillin/streptomycin $(1,000,000$ cells/ml).

Primary dorsal root ganglia (DRG) neurons were obtained from C57BL/6 mice of either sex at 6 weeks of age. Briefly, the spinal column was isolated by dissection and the spinal cord removed by hydraulic extrusion. The spinal cord was split longitudinally and the DRGs located and removed. DRGs were dissociated with collagenase, plated onto poly-L-lysine/laminin-coated plates in DMEM/ nutrient mixture $\mathrm{F}-12$ supplemented with $1 \times \mathrm{N} 1$ and $10 \%$ horse serum $(1,000,000$ cells $/ \mathrm{ml})$.

Immortalized hippocampal neuroblasts (HT22 cells) were cultured in DMEM containing $10 \%$ fetal bovine serum and $1 \%$ penicillin/streptomycin $(50,000$ cells $/ \mathrm{ml})$. HT1080 cells were obtained from American type Culture Collection and cultured in DMEM containing $10 \%$ fetal bovine serum, $1 \%$ penicillin/streptomycin, and $1 \%$ nonessential amino acids (25,000 cells $/ \mathrm{ml})$. Hep3B cells were obtained from American type Culture Collection and cultured in Eagle's minimum essential medium containing $10 \%$ fetal bovine serum and $1 \%$ penicillin/streptomycin $(50,000$ cells $/ \mathrm{ml})$. SH-SY5Y cells were also obtained from American type Culture Collection and cultured in DMEM/ nutrient mixture $\mathrm{F}-12$ containing $10 \%$ fetal bovine serum and $1 \%$ penicillin/streptomycin $(50,000 \mathrm{cell} / \mathrm{ml})$. Cell lines were treated at $24 \mathrm{~h}$ when density reached $70 \%$ confluency.

All cells were cultured at $37^{\circ} \mathrm{C}$ in a humidified $5 \% \mathrm{CO}_{2}$ atmosphere.

\section{Cell viability}

Cell viability was determined at $22-26 \mathrm{~h}$ following erastin or glutamate analog homocysteate (HCA) exposure using MTT assay, a colorimetric assay of cell metabolic activity. We measured the plates at SpectraMax Plus Microplate Reader using SoftMax Pro v4.7.1 (both Molecular Devices). The results of population, quantitative assays of cell viability (MTT) were verified by qualitative LIVE/DEAD assay and fluorescence microscopy at Nikon Eclipse TS100 microscope using Nikon DS-L3 (Nikon Instruments).

\section{Immunoblot analysis}

Protein extracts were prepared using $1 \%$ Triton buffer (in $\mathrm{mm}: 25$ Tris, $\mathrm{pH} 7.4,100 \mathrm{NaCl}, 1$ EGTA, 1\% Triton $\mathrm{X}-100$, protease inhibitors, 2.5 sodium orthovanadate) except in case of the quantification of histones, where RIPA-B lysis buffer (1\% Triton X-100, 1\% SDS, $50 \mathrm{~mm}$ Tris-Cl, pH 7.4, 500 mm NaCl, 1 mm EDTA) was used. We electrophoresed the samples under reducing conditions on NuPAGE gels and transferred them to a nitrocellulose membrane. Antibodies against phospho-S166 RIP1, acetylated histone $\mathrm{H} 4$, total histone $\mathrm{H} 4$, and $\beta$-actin were 
incubated overnight at $4{ }^{\circ} \mathrm{C}$. Secondary antibodies were incubated for $1 \mathrm{~h}$ at room temperature. We detected the proteins using Odyssey infrared imaging system (LI-COR Biosciences).

\section{RNA extraction and real-time PCR}

The total RNA was prepared using the NucleoSpin RNA isolation kit according to established protocols. We performed real-time PCR using TaqMan RNA-to-CT 1-Step Kit for human c-Myc (Hs00153408), p21 (Hs00355782), HDAC1 (Hs00606262_g1), HDAC2 (Hs00231032_m1), HDAC3 (Hs00187320_m1), HDAC8 (Hs00954353_g1), and mouse HDAC1 (Mm02391771), HDAC2 (Mm00515108), HDAC3 (Mm00515916), and HDAC8 (Mm01224980_m1) at a 7500 Real-Time PCR System (Applied Biosystems). Expression levels were normalized to mouse $\beta$-actin endogenous control.

\section{Statistical analysis}

All data represent biological replicates. For the MTT assay, each biological replicate is the mean of four technical replicates. Normality was evaluated with the Kolmogorov-Smirnov test and variance homogeneity using the Levené test. When data were normally distributed and variance was homogeneous, we performed one-way ANOVA followed by the post hoc Bonferroni test. In case one of the criteria was not met, the Kruskal-Wallis test was performed followed by the post hoc Mann-Whitney $U$ test with $\alpha$ correction according to Bonferroni to adjust for the inflation of type I error due to multiple testing. Data are represented as mean \pm SD except for nonparametric data, where medians are given. A value of $p<0.05$ was considered statistically significant. For the Kruskal-Wallis test followed by Mann-Whitney $U, p=0.05 / k$ was used, with $k$ as the number of single hypotheses. $K=2$ for gene expression experiments (comparison of 2 different concentrations vs vehicle-treated cells), $k=4$ (comparison of 3 different concentrations vs vehicle-treated cells) for all nonparametric data of drug treatments, except for Necrostatin-1, Scriptaid, and U0126, where $k=12$ (comparison of 4 different concentrations vs vehicle-treated cells and additional four comparisons vs inactive analog), and pRIP1, where $k=9$ (all vs $0 \mathrm{~h}$ treatment and Necrostatin-1 vs same condition without Necrostatin-1). Thus $\alpha=0.025$ for two comparisons, $\alpha=0.0125$ for four comparisons, $\alpha=0.0056$ for 9 comparisons, and $\alpha=$ 0.0042 for 12 comparisons was considered statistically significant. To analyze contingency tables, Fisher's exact test was used. Detailed statistical analyses can be found in the extended data (Figs. 3-1, 5-1, 7-1, 9-1, 10-1, 13-1, 13-2, 13-3, 13-4, and 14-1). All statistical analyses were performed with IBM SPSS v23 (RRID:SCR_002865).

\section{Results}

\section{Erastin-induced ferroptosis in cancer cells is similar to erastin- and glutamate-induced toxicity in neurons}

Ferroptosis has been shown to be induced by cyst(e)ine deprivation (Fig. 1A; Bridges et al., 2012; Lewerenz et al., 2013) and is operationally defined by sensitivity to a panel of inhibitors targeting macromolecular synthesis (e.g., cycloheximide), reactive lipids (e.g., ferrostatin-1, $N$-acetylcysteine, Trolox), iron (e.g., DFO), and ERK signaling (e.g., U0126; Dixon et al., 2012, 2014). The initial goal of the current studies was to determine whether erastin-induced ferroptosis in cancer cells occurs via mechanisms that are similar or distinct from those induced by erastin in primary neurons.

Incubation of HT1080 fibrosarcoma cells with increasing concentrations of erastin revealed that doses of erastin used previously $(10 \mu \mathrm{M})$ to study the mechanisms of death led to a $95 \%$ reduction in cell survival (Fig. 1B, left), a higher degree of cell death than the $\mathrm{LD}_{50}$ usually targeted for toxicological studies. Studies of chemotherapeutic agents at their $\mathrm{LD}_{50}$ allows one to discern the protective mechanism from the detrimental effects of the chemical and molecular manipulations of cellular pathways. Accordingly, we adjusted the density of HT1080 cells to $70 \%$ confluence before the treatment with different doses of erastin, and found that $1 \mu \mathrm{M}$ is around the $\mathrm{LD}_{50}$ in this particular cell line (Fig. $1 B$, right). In primary neurons, we found the $\mathrm{LD}_{50}$ at around $5 \mu \mathrm{M}$ (Fig. $1 C$, left). Although cortical neuron dysfunction/death may be responsible for "chemo-brain", DRG sensory neurons dysfunction/death is likely responsible for chemotherapyinduced neuropathy. Of note, we also found that erastininduced death of DRG sensory neurons (Fig. 1D). Because it is better characterized, we focused on erastininduced death in cortical neurons for the remainder of our studies.

We performed a systematic analysis of ferroptosis inhibitors of erastin-induced death and confirmed that they prevent erastin-induced toxicity in both $\mathrm{HT} 1080$ cells and primary neurons (Figs. 2, 3). Moreover, live/dead assays, representing a visible, fluorescence microscopic measure of cell death in single cells, revealed results that were similar to quantitative measurements of cell death performed with MTT assays (Fig. 2).

Interestingly, cyst(e)ine or glutathione depletion has been elucidated as an in vitro model of neuronal death in the late 1980s, where glutamate or its analogs were used to induce cell death in cultured neurons (at $2 \mathrm{~d}$ in vitro) via a non-receptor-mediated mechanism involving inhibition of the System $\mathrm{X}_{\mathrm{c}}{ }^{-}$(cystine/glutamate) antiporter (Fig. 1A). This model has been leveraged to understand how cystine deprivation leads to death via oxidative stress (Murphy et al., 1989; Ratan et al., 1994a, b). To determine whether glutamate analog $(\mathrm{HCA})$ and erastin induce neuronal death via similar pathways, we examined the ability of ferroptosis inhibitors to abrogate glutamate analog (HCA)-induced death. We found that glutamate analog (HCA)-induced death (at the $\mathrm{LD}_{50}$ of $5 \mathrm{~mm}$; Fig. $1 \mathrm{C}$, right) was abrogated by inhibitors of ferroptosis (Figs. 2, 3).

\section{Ferroptosis in cancer cells and neurons is abrogated by inhibitors of autophagy and necroptosis}

There are many other modes of cell death (Galluzzi et al., 2018). Apoptosis is a caspase-dependent mode of regulated cell death initiated by perturbations of the intracellular (intrinsic apoptosis) or extracellular (extrinsic ap- 
A Actinomycin D, Cycloheximide
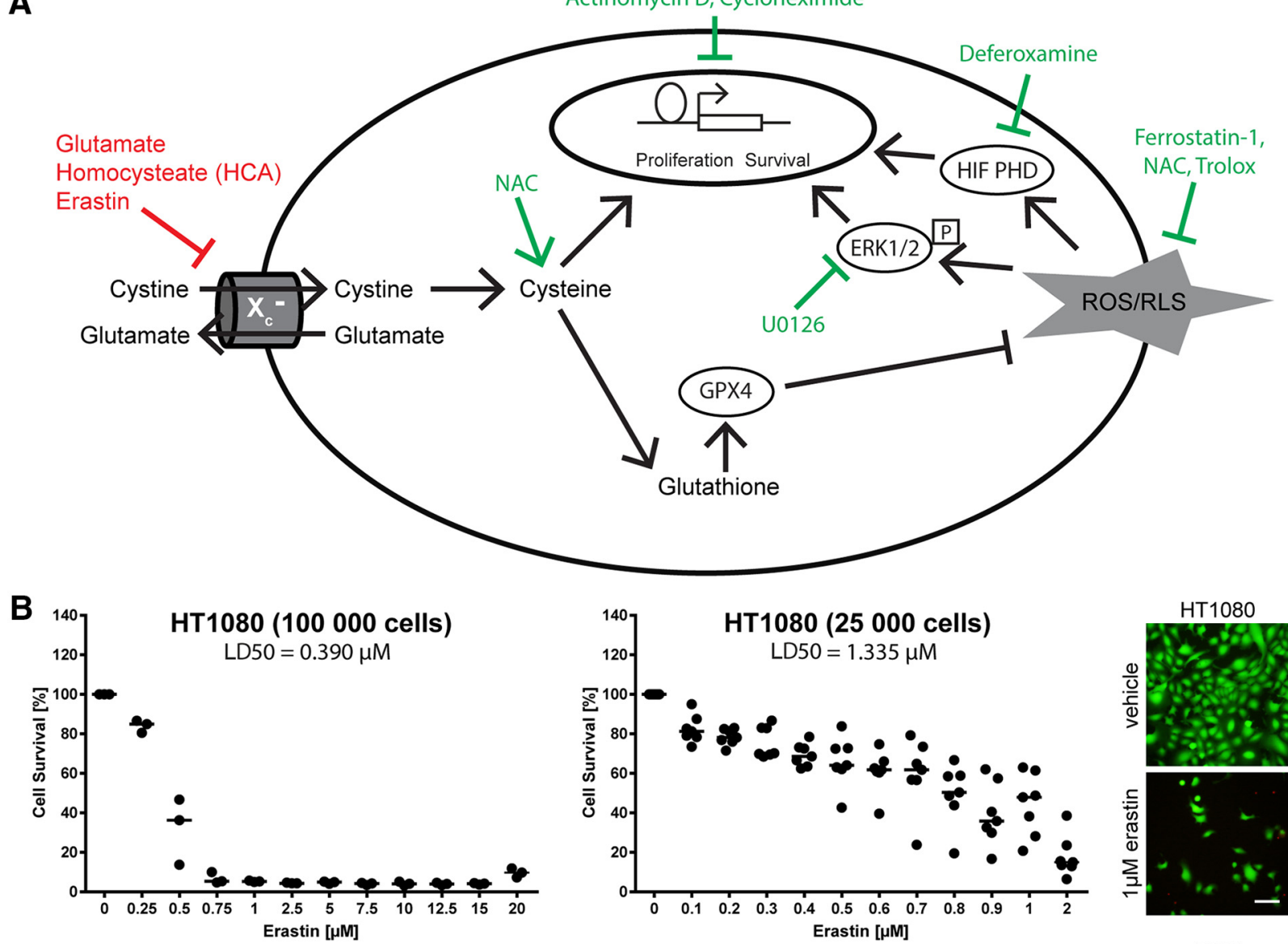

C
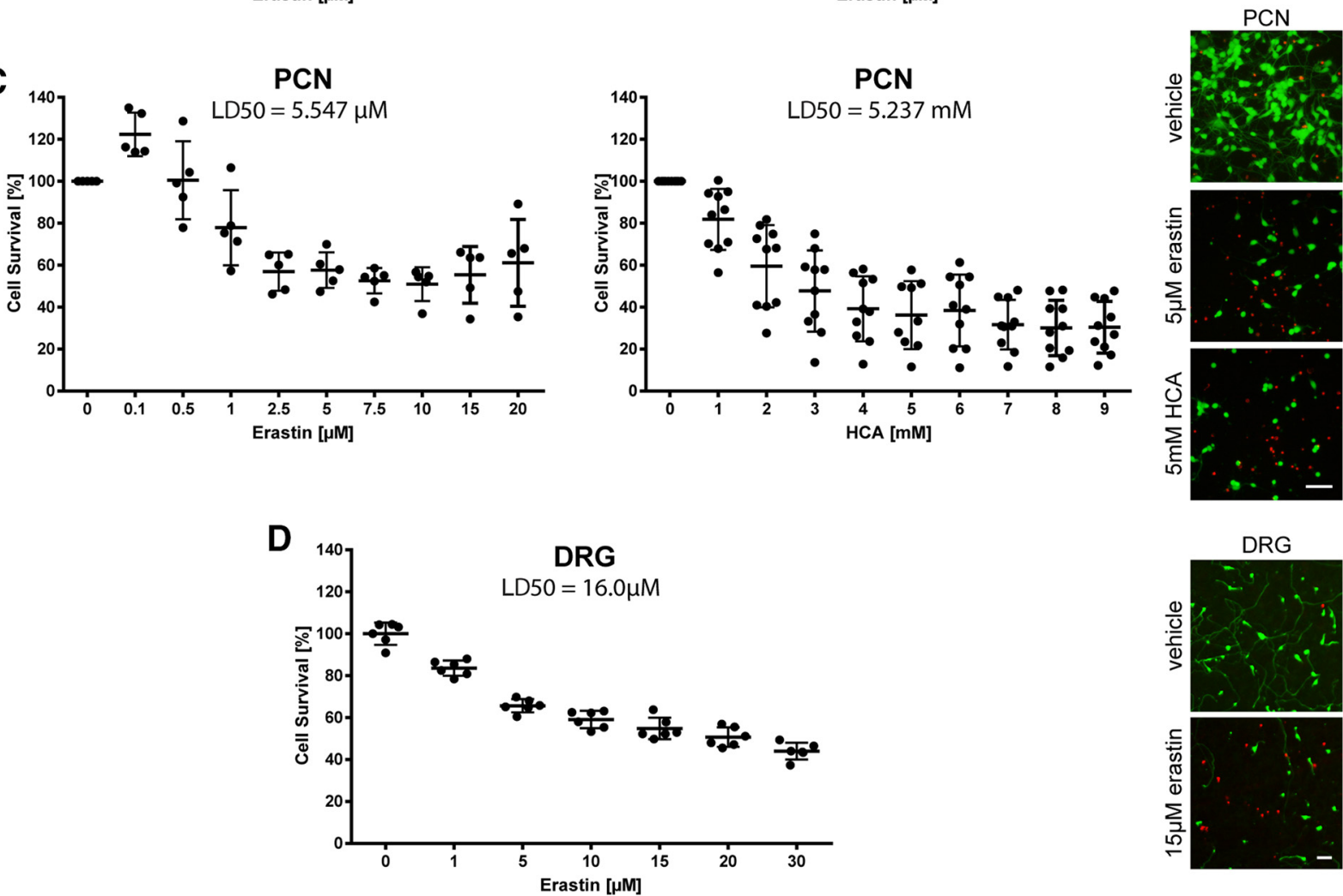

Figure 1. Models of cysteine deprivation. $\boldsymbol{A}$, The ferroptosis inhibitor erastin is a selective inhibitor of the $\mathrm{X}_{\mathrm{c}-}$ transporter. Similarly, in cells devoid of ionotropic glutamate receptors, such as tumor cells and immature neurons, glutamate and its analog HCA work as 


\section{continued}

nonspecific inhibitors of the System $\mathrm{X}_{\mathrm{c}-}$ transporter by counteracting the glutamate gradient resulting in reduced uptake of cystine into the cells. This leads to a decrease in glutathione synthesis, which is essential for the endogenous antioxidant defense. Ferroptosis inhibitors are indicated in green. NAC, $\mathrm{N}$-acetylcysteine. $\boldsymbol{B}, \mathrm{HT} 1080$ fibrosarcoma cells were treated with increasing dose of erastin at previously described density (left; 100,000 cells $/ \mathrm{ml}$ ) and adjusted density to reach $70 \%$ confluency before treatment (right; 25,000 cells $/ \mathrm{ml}$ ) to determine the toxicologically meaningful dose of erastin. Representative live/dead staining are shown, green indicating live cells (calcein AM) and red indicating dead cells (ethidium homodimer-1). Scale bar, $50 \mu \mathrm{m}$. C, Dose-response of erastin (left) and HCA (right) in primary cortical neurons. Representative live/dead staining are shown. Scale bar, $50 \mu \mathrm{m}$. $\boldsymbol{D}$, Dose-response of erastin in DRG neurons and representative live/dead staining. Scale bar, $100 \mu \mathrm{m}$.

optosis) microenvironment, whereas parthanatos is pathway-dependent on apoptosis-inducing factor that is induced by poly(ADP-ribose) polymerase 1 hyperactivation. We found that erastin-induced death of HT1080 fibrosarcoma cells or primary neurons, as well as glutamate analog (HCA)-induced death of primary neurons, was not altered by inhibitors of apoptosis or parthanatos (Figs. 4-7).

Unexpectedly, several modulators of autophagy (Bafilomycin A1, Chloroquine, and rapamycin; (Pasquier, 2016) abrogated erastin-induced cell death in HT1080 fibrosarcoma cells. In primary neurons, the autophagy inducer rapamycin decreased both erastin- and glutamate analog (HCA)-induced toxicity. In addition, we found a significant increase in viability with the autophagy inhibitors 3methyladenine and Bafilomycin A1 in glutamate analog (HCA)-induced neuronal death (Figs. 8, 9).

Necroptosis is another mode of regulated cell death that depends on the activation of receptor-interacting proteins (RIPs; Degterev et al., 2005; Sun et al., 2012). The RIP1 inhibitor Necrostatin-1 abrogated erastin-induced cell death in HT1080 cells and primary neurons as well as glutamate analog (HCA)-induced neuronal toxicity. In addition, the RIP3 inhibitor GSK872 blocked neuronal cell death from erastin and glutamate analog (HCA) and the inhibitor of mixed lineage kinase domain-like protein (MLKL), necrosulfonamide, prevented erastin toxicity in HT1080 cells (Figs. 6, 7).

The specificity of Necrostatin-1 against RIP1 was suggested by a structural analog (Necrostatin-1i), with no activity toward RIP1, that did not block erastin- or glutamate analog (HCA)-induced toxicity. Moreover, as RIP1 kinase activity is required to execute necroptosis (Berger et al., 2014), we assessed the ability of erastin to induce active RIP kinase using an antibody against a known RIP1 autophosphorylation site at serine 166 (Guo et al., 2015). We found a Necrostatin-1-sensitive increase in phosphoRIP1 following erastin and glutamate analog (HCA) treatment in HT22 mouse hippocampal neuronal cells (Fig. 10). These cells also died in response to both inducers of cyst(e)ine/glutathione depletion.

To elucidate whether erastin- and glutamate analog (HCA)-induced toxicities are similar or distinct modes of cell death (Fig. 11A), we performed statistical comparisons between the inhibitor profiles (Fig. 11B). First, we found that erastin toxicity in HT1080 fibrosarcoma cells can be considered ferroptosis as previously described (Dixon et al., 2012; Fisher's exact test, two-tailed, $p=$ 0.202), despite the ability of the inducers of autophagy or the inhibitors of necroptosis to prevent "ferroptosis" at the lower dose $(1 \mu \mathrm{M})$ in HT1080 cells. Second, erastin toxicity in HT1080 fibrosarcoma cells and in neurons can be considered mechanistically similar (Fisher's exact test, two-tailed, $p=0.350)$. Similarly, erastin and glutamate analog (HCA) toxicity in neurons can be considered mechanistically similar (Fisher's exact test, two-tailed, $p=$ 0.758).

Collectively, these findings suggest that erastin induces cell death in both cancer cells and neurons through ferroptotic, autophagic, and necroptotic pathways and that they are not different from what is known from the established glutathione depletion model referred to incorrectly as apoptosis (Ratan et al., 1994b) or correctly as oxytosis (Lewerenz et al., 2018) in prior studies (Fig. 11B; Fisher's exact test, two-tailed, $p=0.751$ ). Convergence of these distinct modes of cell death in a single cell death paradigm has not been described so far.

\section{Promoting cancer cell death while protecting neurons}

Because erastin toxicity in HT1080 cells and glutamate analog (HCA)-induced glutathione depletion in neurons induce ferroptotic cell death, we hypothesized that prior knowledge about glutamate analog (HCA)-induced ferroptosis in neurons should inform the points of convergence and divergence with erastin-induced ferroptosis in HT1080 fibrosarcoma cells. We therefore investigated whether erastin-induced ferroptosis in HT1080 can be abolished or exacerbated by the chemical inhibitors known to be effective in glutamate analog (HCA)-induced neuronal ferroptosis (Figs. 12, 13A).

Glutamate analog (HCA)-induced ferroptosis in neurons requires de novo transcription via the leucine zipper transcription factor ATF4 leading to upregulation of putative pro-death genes such as Trib3, Chop, and Chac1 (Lange et al., 2008; Karuppagounder et al., 2016). Recently, it was shown that HIF prolyl hydroxylases (HIF PHDs) are required for pro-death ATF4 transcription, and a selective small molecule inhibitor of the HIF PHDs, Adaptaquin, abrogates glutamate analog (HCA)-induced ferroptosis and improves functional recovery after intracerebral hemorrhage, where cell death has also been defined as ferroptotic (Karuppagounder et al., 2016). As expected from these findings, Adaptaquin also protected against erastininduced toxicity in HT1080 cells (Figs. 12, 13A).

Prior studies have shown that, like Adaptaquin, the aureolic acid antitumor agent Mithramycin can also act in the nucleus to abrogate glutamate analog (HCA)-induced ferroptosis in vitro and extend survival in vivo in an HD model, where ferroptosis has also been implicated 


\section{A}

\begin{tabular}{|c|c|c|c|c|c|c|c|}
\hline \begin{tabular}{|l|} 
Cell Death \\
Mechanism \\
\end{tabular} & Subcategory & Cell Death Inhibitor & Target & Concentrations & HT1080 Erastin & PCN Erastin & PCN HCA \\
\hline \multicolumn{5}{|c|}{ vehicle } & $30.93 \pm 13.29$ & $41.97 \pm 15.77$ & $37.10 \pm 17.41$ \\
\hline \multirow{8}{*}{$\begin{array}{l}\text { Regulated } \\
\text { Necrosis }\end{array}$} & \multirow{8}{*}{ Ferroptosis } & Actinomycin D & mRNA synthesis & $0.001-1 \mu \mathrm{M}$ & $\begin{array}{c}62.15 \pm 21.36 \text { * } \\
(10 \mathrm{nM})\end{array}$ & $\begin{array}{c}73.44 \pm 5.72^{*} \\
(1 \mathrm{nM}) \\
\end{array}$ & $\begin{array}{c}45.88 \pm 28.37 \\
(1 \mathrm{nM})\end{array}$ \\
\hline & & Cycloheximide & Protein synthesis & $0.1-50 \mu \mathrm{M}$ & $\begin{array}{c}49.77 \pm 10.43^{*} \\
(1 \mu \mathrm{M})\end{array}$ & $\begin{array}{c}76.55 \pm 20.94 \\
(1 \mu \mathrm{M}) \\
\end{array}$ & $\begin{array}{c}81.22 \pm 8.62 * \\
(0.1 \mu \mathrm{M})\end{array}$ \\
\hline & & Ferrostatin-1 & $\begin{array}{l}\text { Canonical ferroptosis inhibitor, } \\
\text { reactive lipid species (RLS) }\end{array}$ & $0.01-10 \mu \mathrm{M}$ & $\begin{array}{c}98.12 \pm 12.20 * \\
(0.1 \mu \mathrm{M})\end{array}$ & $\begin{array}{c}87.46 \pm 11.04 \text { * } \\
(0.1 \mu \mathrm{M})\end{array}$ & $\begin{array}{c}93.44 \pm 6.08^{*} \\
(0.1 \mu \mathrm{M})\end{array}$ \\
\hline & & Deferoxamine & $\begin{array}{l}\text { Iron, hypoxia-inducible factor (HIF) } \\
\text { prolyl hydroxylase domain- } \\
\text { containing (PHD) inhibition }\end{array}$ & $10-100 \mu \mathrm{M}$ & $\begin{array}{c}82.25 \pm 12.31 * \\
(10 \mu \mathrm{M})\end{array}$ & $\begin{array}{c}85.60 \pm 13.31 \text { * } \\
(50 \mu \mathrm{M})\end{array}$ & $\begin{array}{c}81.00 \pm 10.28 \text { * } \\
(50 \mu \mathrm{M})\end{array}$ \\
\hline & & N-Acetylcysteine & $\begin{array}{l}\text { Reactive oxygen species (ROS), } \\
\text { RLS }\end{array}$ & $100-1000 \mu \mathrm{M}$ & $\begin{array}{c}110.26 \pm 18.37 \\
*(500 \mu \mathrm{M})\end{array}$ & $\begin{array}{c}112.10 \pm 13.17 \\
*(100 \mu \mathrm{M})\end{array}$ & $\begin{array}{c}102.50 \pm 9.05^{*} \\
(100 \mu \mathrm{M})\end{array}$ \\
\hline & & Trolox, vitamin E analog & RLS & $0.1-100 \mu \mathrm{M}$ & $\begin{array}{c}113.80 \pm 9.41^{*} \\
(100 \mu \mathrm{M})\end{array}$ & $\begin{array}{c}118.69 \pm 7.02 \text { * } \\
(100 \mu \mathrm{M})\end{array}$ & $\begin{array}{c}115.05 \pm 10.84 \\
*(100 \mu \mathrm{M})\end{array}$ \\
\hline & & U0126 & $\begin{array}{l}\text { Mitogen-activated protein kinase } \\
\text { kinase } 1 / 2 \text { (MEK 1/2) }\end{array}$ & $1-20 \mu \mathrm{M}$ & $\begin{array}{c}78.88 \pm 4.76 * \# \\
(5 \mu \mathrm{M})\end{array}$ & $\begin{array}{c}97.57 \pm 5.566^{*} \# \\
(5 \mu \mathrm{M})\end{array}$ & $\begin{array}{c}95.80 \pm 8.21^{*} \# \\
(5 \mu \mathrm{M})\end{array}$ \\
\hline & & U0124 & Inactive U0126 analog & $1-20 \mu \mathrm{M}$ & $\begin{array}{c}38.79 \pm 16.11 \\
(5 \mu \mathrm{M})\end{array}$ & $\begin{array}{c}34.39 \pm 14.03 \\
(5 \mu \mathrm{M})\end{array}$ & $\begin{array}{c}17.35 \pm 9.23 \\
(5 \mu \mathrm{M})\end{array}$ \\
\hline
\end{tabular}

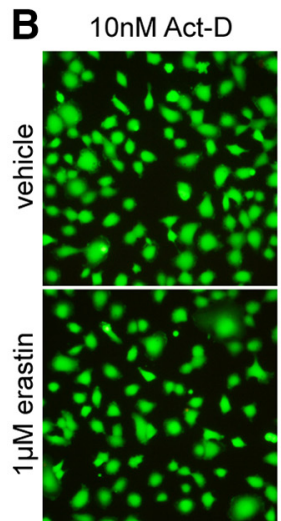

$0.1 \mu \mathrm{M}$ Fer-1

$10 \mu \mathrm{M}$ DFO

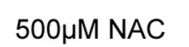

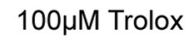

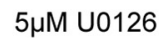

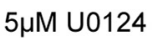
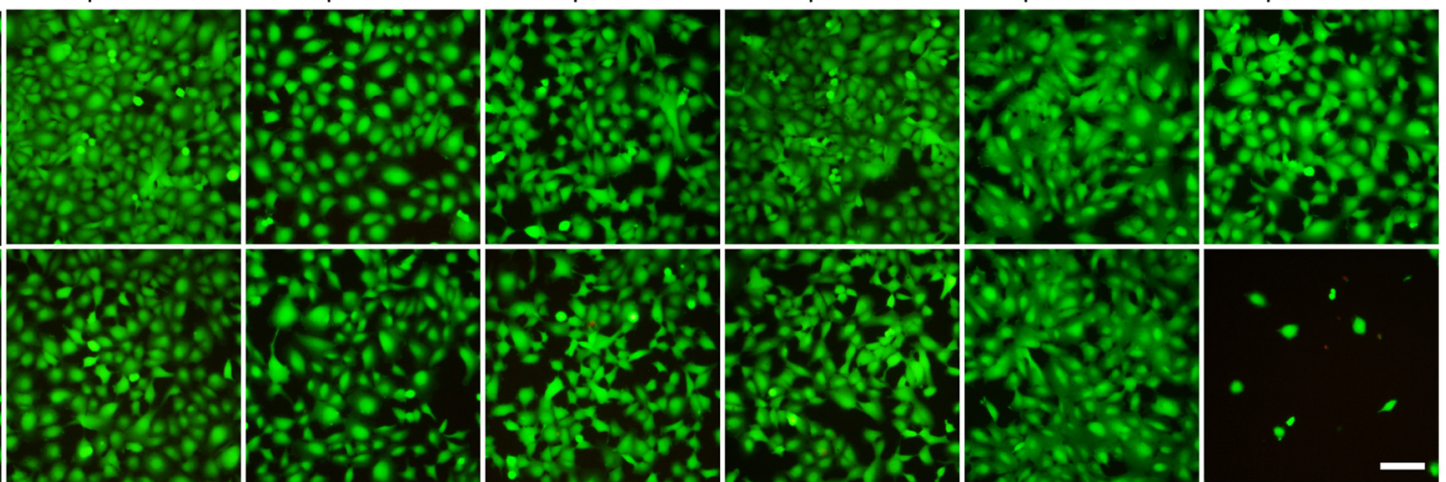

C 1 nM Act-D

$0.1 \mu \mathrm{M}$ Fer-1

$50 \mu \mathrm{M}$ DFO

$100 \mu M$ NAC
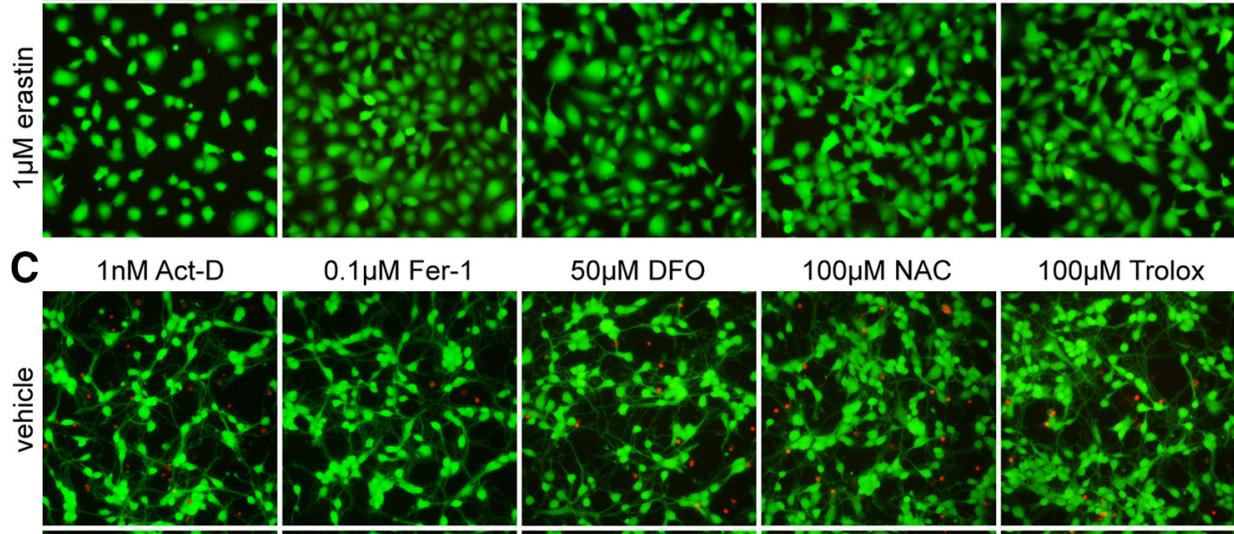

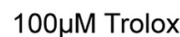

$5 \mu \mathrm{M}$ บ0126
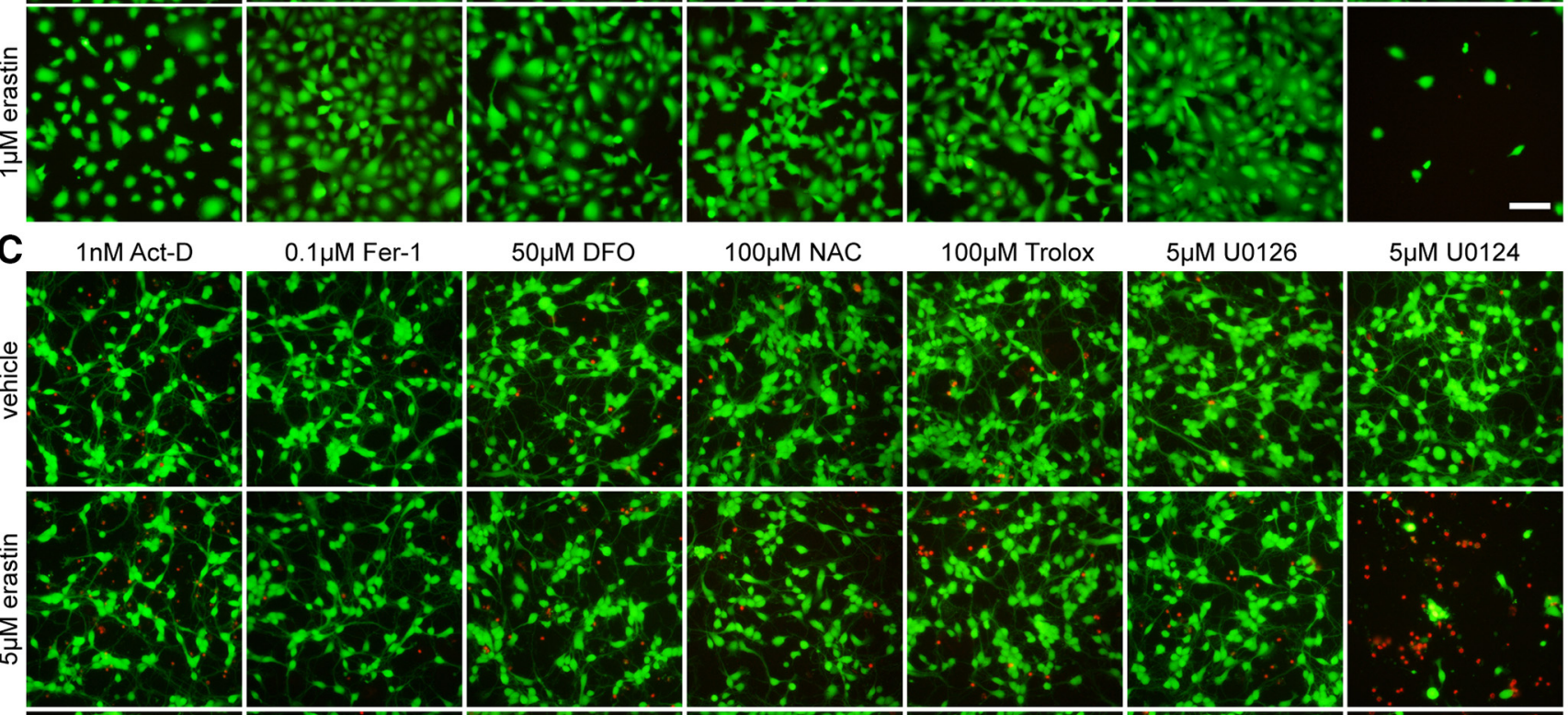

$5 \mu \mathrm{M}$ บ0124
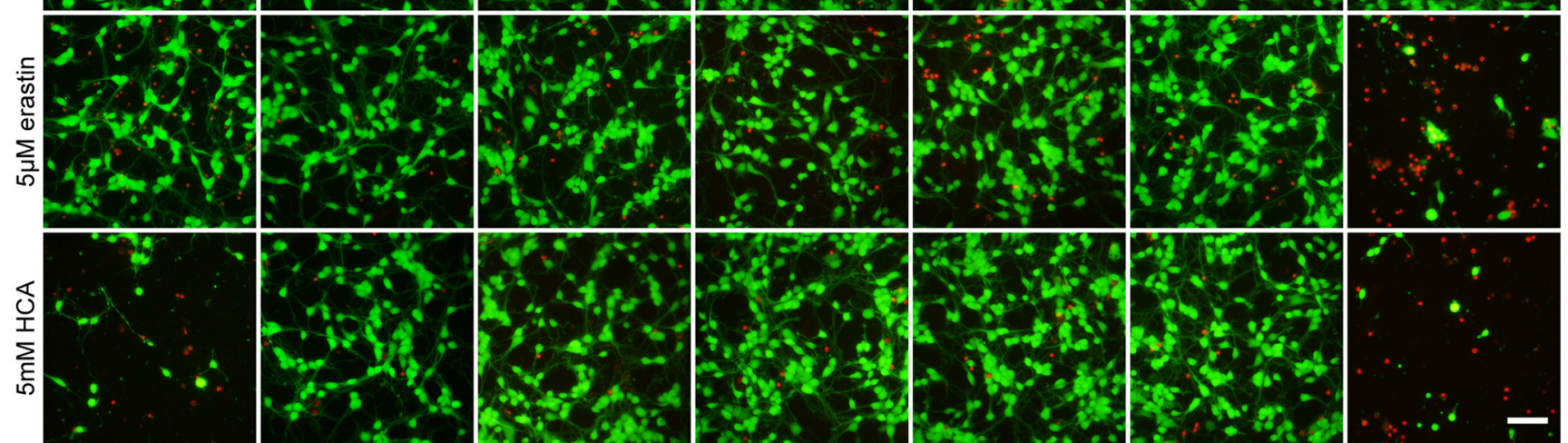

Figure 2. Ferroptosis inhibitors abrogate ferroptosis in cancer cells (HT1080) and primary cortical neurons (PCNs). $\boldsymbol{A}$, HT1080 cells were treated with $1 \mu \mathrm{M}$ erastin, PCNs with $5 \mu \mathrm{M}$ erastin or $5 \mathrm{mM}$ glutamate analog HCA (all $\mathrm{LD}_{50}$ ) glutamate analog HCA and chemical inhibitors effective in ferroptosis were examined. Numbers show mean \pm SD at representative concentration in brackets. Grayscale coding indicates the continuum from no protection in the presence of erastin (black) to maximal cell viability (white). $* p<0.05$ versus erastin or glutamate analog $(\mathrm{HCA}), \# p<0.05$ versus inactive analog U0124. $\boldsymbol{B}, \boldsymbol{C}$, Representative live/dead staining in $\mathrm{HT} 1080$ cells $(\boldsymbol{B})$ and PCN $(\boldsymbol{C})$ are shown, green indicating live cells (calcein AM) and red indicating dead cells (ethidium homodimer-1). Images for cycloheximide are shown in Figure 8 because it is also a criterion for apoptosis. Scale bar, $50 \mu \mathrm{m}$. 
A

HT1080

- vehicle $\quad{ }_{1 \mu \mathrm{M} \text { erastin }}$
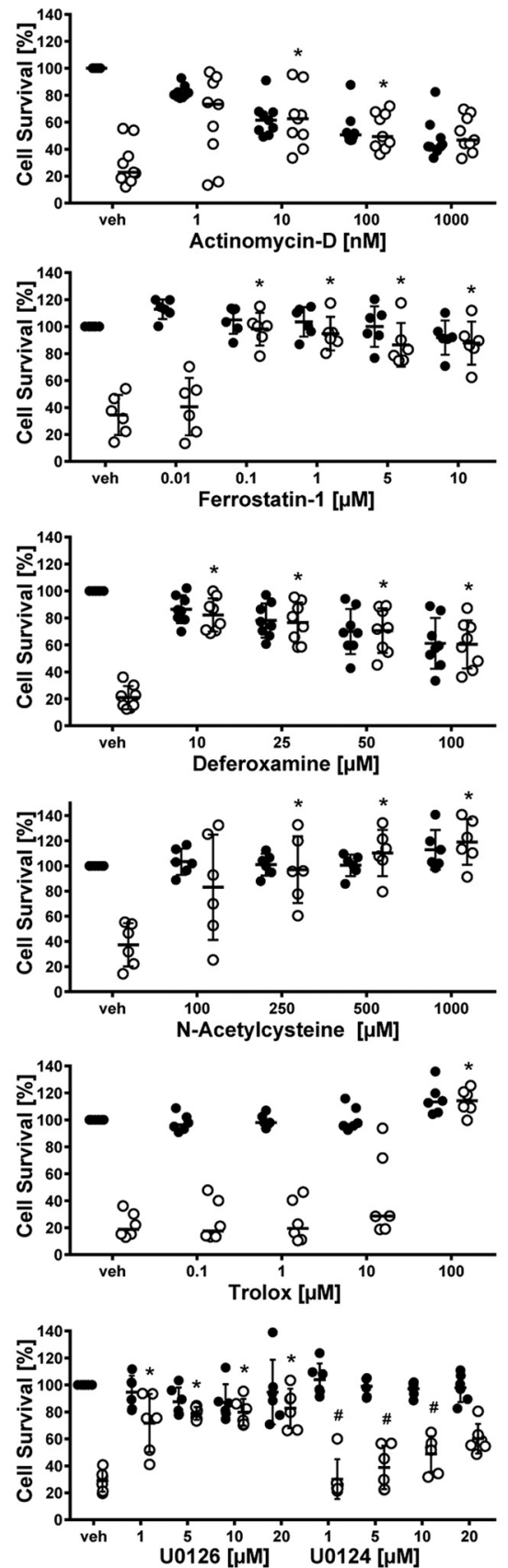

B
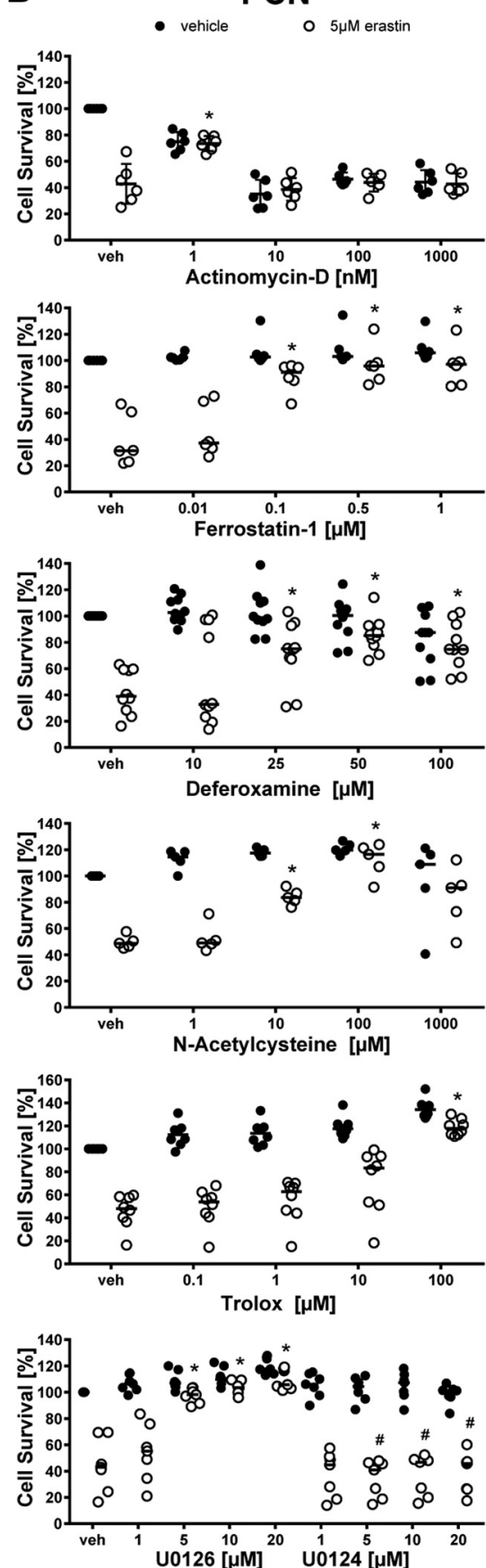

C PCN
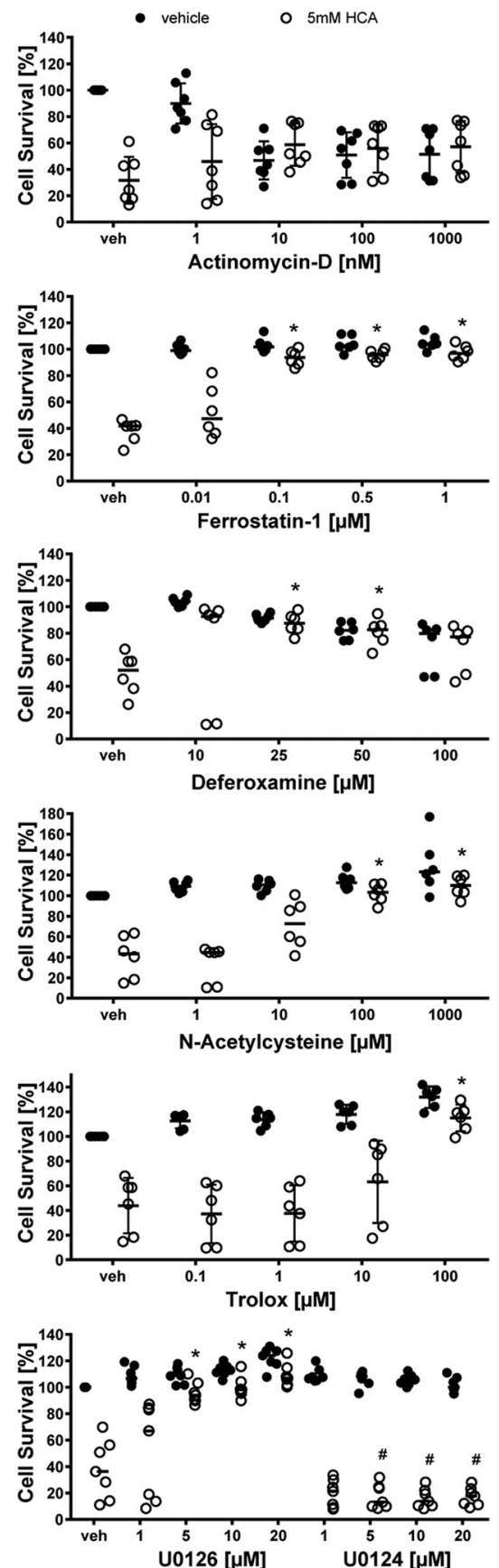

Figure 3. Dose-responses of ferroptosis inhibitors in cancer cells (HT1080) and primary cortical neurons (PCNs). HT1080 cells were treated with $1 \mu \mathrm{M}$ erastin, PCN with $5 \mu \mathrm{M}$ erastin or $5 \mathrm{mM}$ glutamate analog HCA and chemical inhibitors effective in ferroptosis were examined. Dose-response for cycloheximide is shown in Figure 9 because it is also a criterion for apoptosis. Values represent mean \pm SD, except for actinomycin D and Trolox in HT1080 cells, Ferrostatin-1, Deferoxamine, $N$-acetylcysteine, Trolox, and U0126 in PCN treated with erastin as well as Ferrostatin-1, Deferoxamine, $\mathrm{N}$-acetylcysteine, and U0126 in PCNs treated with glutamate analog $(\mathrm{HCA})$ where medians are given. $* p<0.05$ versus erastin or glutamate analog $(\mathrm{HCA}), \# p<0.05$ versus U0124. For exact $p$ values refer to Figure $3-1$.

(Chatterjee et al., 2001; Ferrante et al., 2004; Sleiman et al., 2011a, b). Mithramycin inhibits ferroptosis by acting in a gene-selective way to inhibit Sp1-dependent genes. For example, oncogenic and pro-death c-Myc is suppressed by Mithramycin, but protective p21 waf1/cip1 is induced. Given the ability of this established anticancer drug to abrogate glutamate analog-induced ferroptosis in neurons, we examined its effect in erastin-induced cell death in HT1080 cells. Unexpectedly, Mithramycin (50$300 \mathrm{~nm}$ ) abrogated erastin-induced death in cancer cells 


\section{A}

\begin{tabular}{|c|c|c|c|c|c|c|}
\hline Cell Death Mechanism & Cell Death Inhibitor & Target & Concentration & |HT1080 Erastin | & PCN Erastin & PCN HCA \\
\hline \multicolumn{4}{|c|}{ vehicle } & $30.93 \pm 13.29$ & $41.97 \pm 15.77$ & $37.10 \pm 17.41$ \\
\hline \multirow{5}{*}{$\begin{array}{l}\text { Caspase-dependent } \\
\text { apoptosis }\end{array}$} & z-VAD-fmk & Caspases & $0.1-100 \mu \mathrm{M}$ & $\begin{array}{c}22.72 \pm 8.10 \\
(100 \mu \mathrm{M})\end{array}$ & $\begin{array}{c}18.26 \pm 11.01 \\
(100 \mu \mathrm{M})\end{array}$ & $\begin{array}{c}11.86 \pm 3.76 \\
(100 \mu \mathrm{M})\end{array}$ \\
\hline & Cycloheximide & Protein synthesis & $0.1-50 \mu \mathrm{M}$ & $\begin{array}{c}49.77 \pm 10.43 * \\
(1 \mu \mathrm{M})\end{array}$ & $\begin{array}{c}76.55 \pm 20.94 \\
(1 \mu \mathrm{M})\end{array}$ & $\begin{array}{c}81.22 \pm 8.62 \text { * } \\
(0.1 \mu \mathrm{M})\end{array}$ \\
\hline & Cyclosporin A & $\begin{array}{l}\text { Cyclophilin D (mitoch. permeability } \\
\text { transition pore) }\end{array}$ & $0.1-10 \mu \mathrm{M}$ & $\begin{array}{c}54.39 \pm 6.74 \text { * } \\
(10 \mu M)\end{array}$ & $\begin{array}{c}55.70 \pm 27.68 \\
(10 \mu \mathrm{M})\end{array}$ & $\begin{array}{c}20.75 \pm 13.78 \\
(10 \mu \mathrm{M})\end{array}$ \\
\hline & SB203580 & $\begin{array}{l}\text { p38 mitogen-activated protein } \\
\text { (MAP) kinase (p38) }\end{array}$ & $1-30 \mu \mathrm{M}$ & $\begin{array}{c}22.37 \pm 10.26 \\
(10 \mu \mathrm{M})\end{array}$ & $\begin{array}{c}59.59 \pm 23.70 \\
(10 \mu M)\end{array}$ & $\begin{array}{c}9.20 \pm 1.62 \text { * } \\
(10 \mu \mathrm{M})\end{array}$ \\
\hline & SP600125 & c-JUN N-terminal kinase (JNK) & $0.01-5 \mu \mathrm{M}$ & $\begin{array}{c}30.75 \pm 5.43 \\
(5 \mu \mathrm{M})\end{array}$ & $\begin{array}{c}32.93 \pm 15.29 \\
(5 \mu \mathrm{M})\end{array}$ & $\begin{array}{c}8.87 \pm 1.51 \text { * } \\
(5 \mu \mathrm{M})\end{array}$ \\
\hline
\end{tabular}
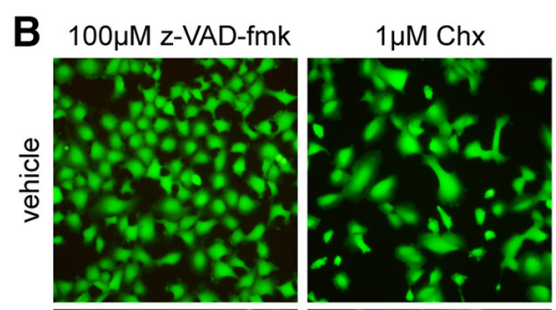

$10 \mu \mathrm{M}$ CsA

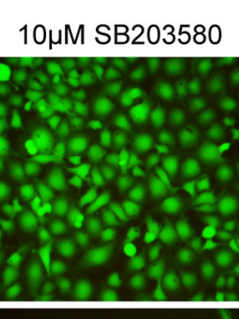

54M SP600125
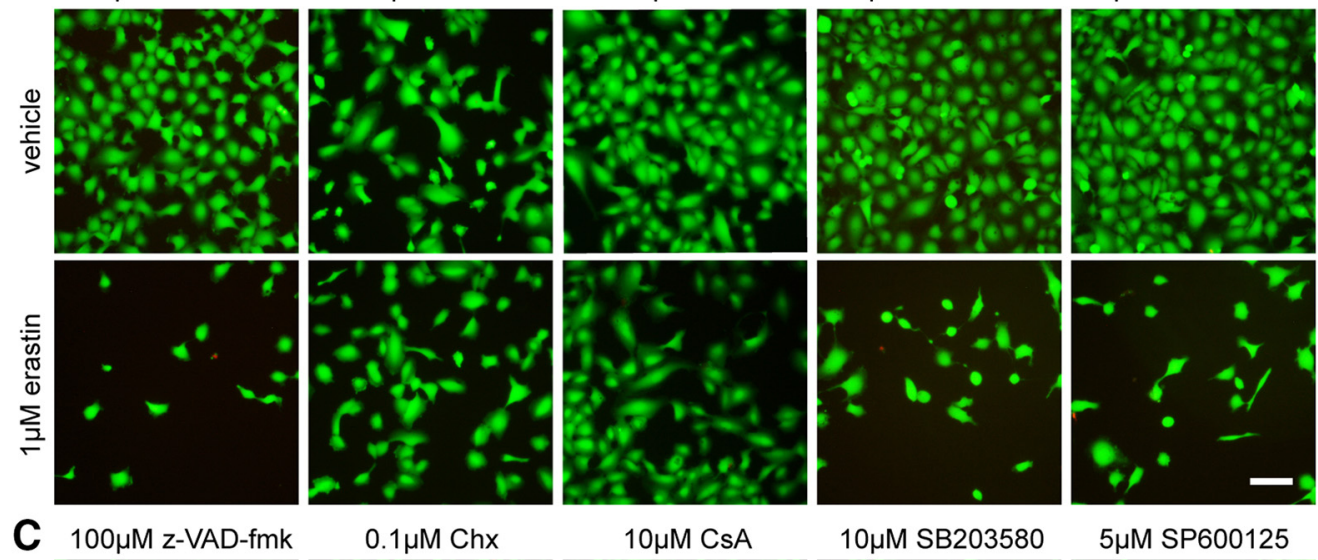

$0.1 \mu \mathrm{M}$ Chx

$10 \mu \mathrm{M}$ CsA

$10 \mu \mathrm{M}$ SB203580

$5 \mu \mathrm{M}$ SP600125
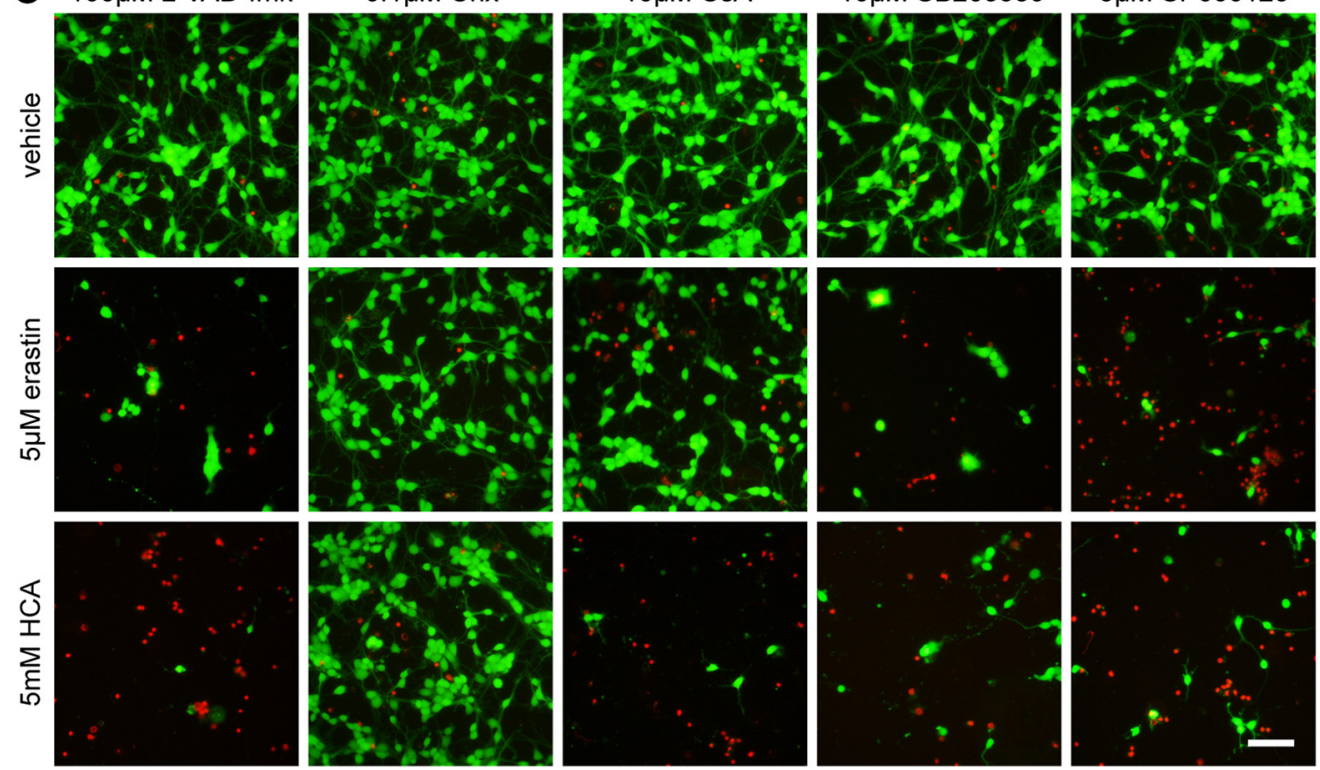

Figure 4. Apoptosis inhibitors do not inhibit ferroptosis in cancer cells (HT1080) and primary cortical neurons (PCNs). A, HT1080 cells were treated with $1 \mu \mathrm{M}$ erastin, PCN with $5 \mu \mathrm{M}$ erastin or $5 \mathrm{mM}$ glutamate analog HCA and chemical inhibitors effective in apoptosis were examined. Numbers show mean \pm SD at representative concentration in brackets. Grayscale coding indicates the continuum from no protection in the presence of erastin (black) to maximal cell viability (white). $* p<0.05$ versus erastin or glutamate analog (HCA). B, C , Representative live/dead staining in HT1080 cells $(\boldsymbol{B})$ and PCNs $(\boldsymbol{C})$ are shown, green indicating live cells (calcein AM) and red indicating dead cells (ethidium homodimer-1). Scale bar, $50 \mu \mathrm{m}$.

(Figs. 12, 13A). We confirmed that Mithramycin was able to induce p21 gene expression in HT1080 cells, but failed to reduce basal c-Myc levels suggesting the possibility that augmentation of tumor suppression genes rather than suppression of proto-oncogenes may mediate Mith- ramycin's effects in HT1080 cells (Fig. 13B; Sleiman et al., 2011b).

Transglutaminases are established transcriptional targets for Huntington's disease (McConoughey et al., 2010) and have been shown to mediate glutamate analog 
A
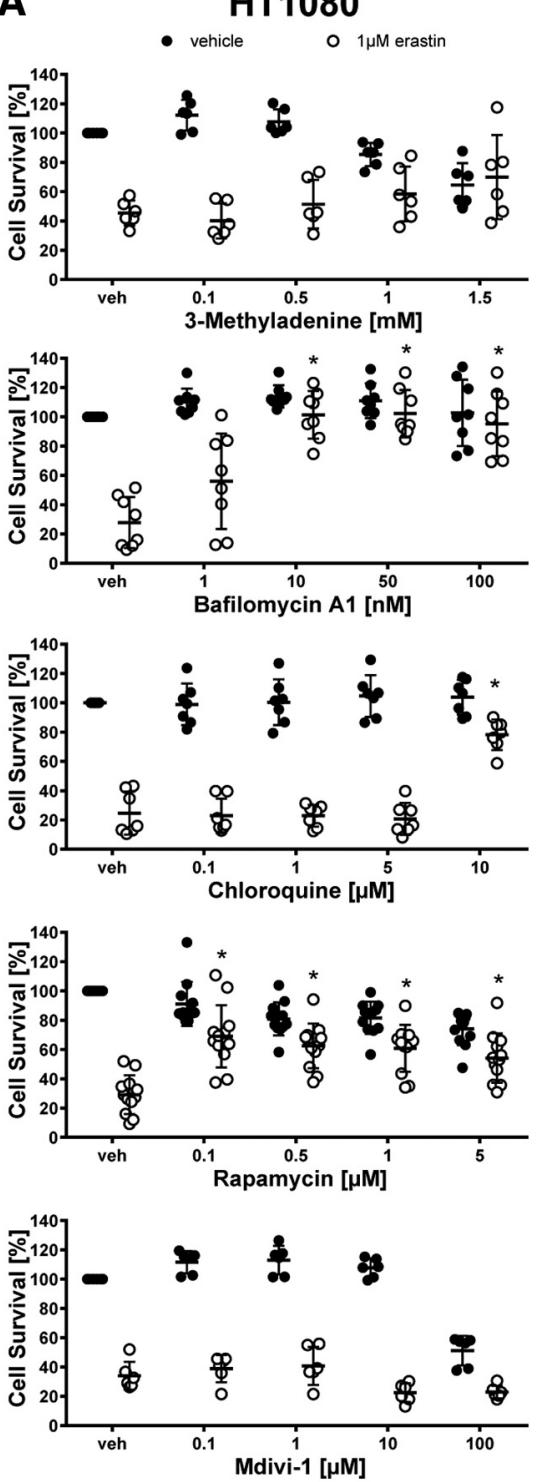

B
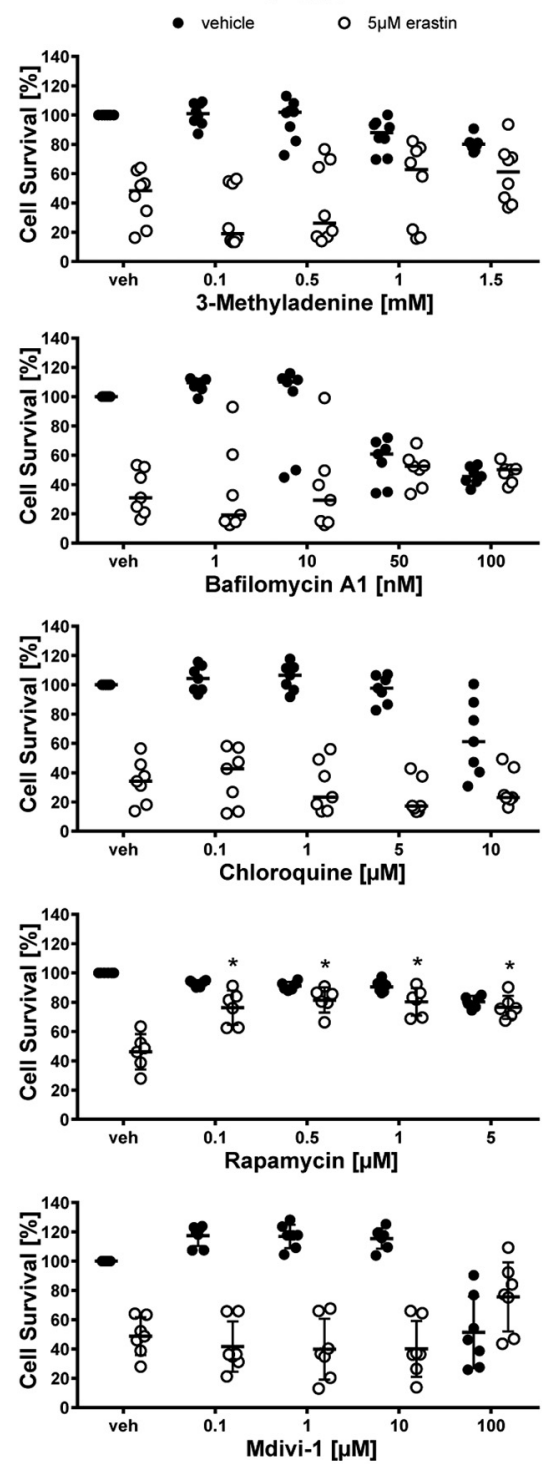

C PCN
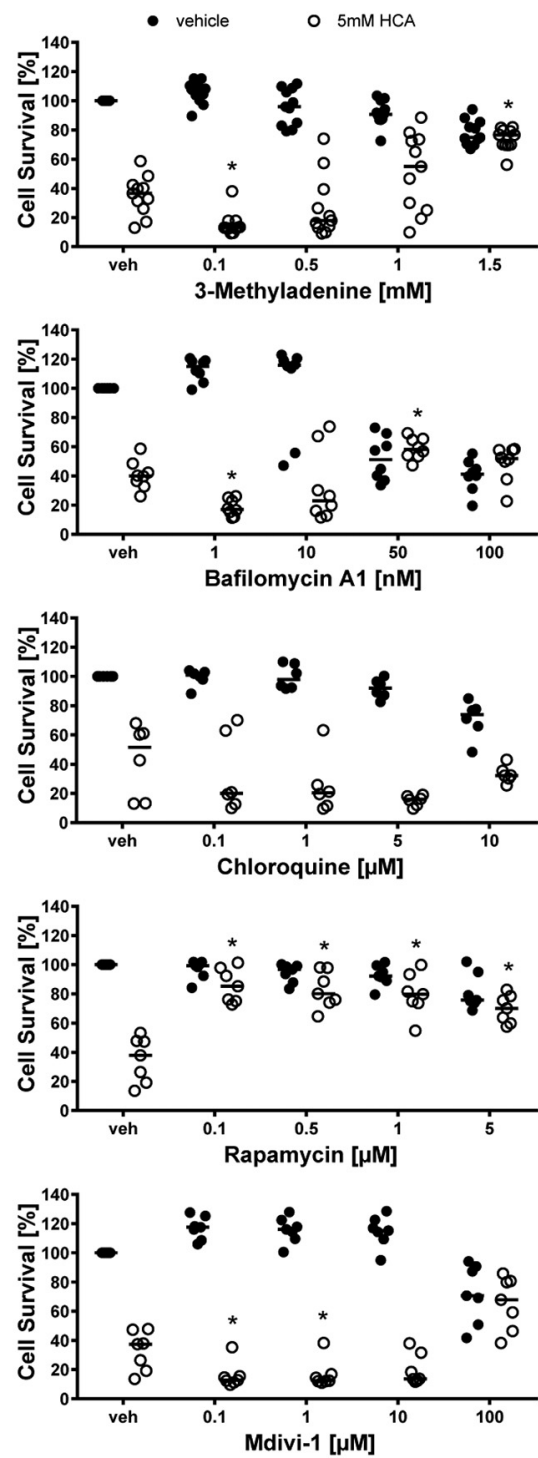

Figure 5. Dose-responses of apoptosis inhibitors in cancer cells (HT1080) and primary cortical neurons (PCNs). HT1080 cells were treated with $1 \mu \mathrm{M}$ erastin, PCN with $5 \mu \mathrm{M}$ erastin or $5 \mathrm{mM}$ glutamate analog HCA and chemical inhibitors effective in apoptosis were examined. Values represent mean \pm SD, except for cyclosporin A, SP600125, cycloheximide in HT1080 cells, cyclosporin A in PCNs treated with erastin as well as z-VAD-fmk, cyclosporin A, SB203580, SP600125 in PCNs treated with glutamate analog (HCA) where medians are given. $* p<0.05$ versus erastin or glutamate analog (HCA). For exact $p$ values refer to Figure 5-1.

(HCA)-induced ferroptosis via their effects in the nucleus, downstream of the hyperactivation of ERK signaling (a cardinal feature of ferroptosis; Basso et al., 2012). As transglutaminases have also been implicated as survival factors for tumors, we reasoned that the inhibitors of transglutaminases may protect neurons while exacerbating HT1080 fibrosarcoma-induced ferroptosis. However, two structurally diverse transglutaminase inhibitors also inhibited erastin-induced ferroptosis in HT1080 fibrosarcoma cells (Figs. 12, 13A), further demonstrating convergence between cyst(e)ine deprivation in transformed fibrosarcoma cells and non-transformed neurons.

Another class of agents with known antitumor activity shown to abrogate HCA-induced ferroptosis are class I HDAC inhibitors (Ryu et al., 2003; Langley et al., 2008;
Sleiman et al., 2011a, 2014). Structurally diverse HDAC inhibitors including Butyrate, Scriptaid, and Trichostatin $A$, all prevent HDAC-induced ferroptosis in neurons (Ryu et al., 2003). By contrast to Adaptaquin, Mithramycin A, and transglutaminase inhibitors, class I HDAC inhibitors failed to protect HT1080 cells from erastin toxicity, in fact, they exacerbated cell death (Figs. 12, Fig. 13A). In contrast, Scriptaid, which was able to protect neurons from ferroptosis (Fig. 13C), did not exacerbate ferroptosis in cancer cells. We confirmed that Scriptaid but not its structurally similar, inactive analog Nullscript, increased the acetylation of histones using Western blotting (Fig. 13D).

We then hypothesized that the expression of distinct HDAC isoforms in neurons versus cancer cells explains this difference. We therefore assessed the gene expres- 


\section{A}

\begin{tabular}{|c|c|c|c|c|c|c|c|}
\hline \begin{tabular}{|l|} 
Cell Death \\
Mechanism \\
\end{tabular} & Subcategory & Cell Death Inhibitor & Target & Concentrations & HT1080 Erastin | & PCN Erastin & PCN HCA \\
\hline \multicolumn{5}{|c|}{ vehicle } & $30.93 \pm 13.29$ & $41.97 \pm 15.77$ & $37.10 \pm 17.41$ \\
\hline \multirow{6}{*}{$\begin{array}{l}\text { Regulated } \\
\text { Necrosis }\end{array}$} & \multirow[b]{2}{*}{ Parthanatos } & DPQ, PARP inhibitor III & $\begin{array}{l}\text { Poly(ADP-ribose) polymerase } 1 \\
\text { and } 2 \text { (PARP1 and 2) }\end{array}$ & $0.1-50 \mu \mathrm{M}$ & $\begin{array}{c}74.31 \pm 9.20^{*} \\
(50 \mu \mathrm{M})\end{array}$ & $\begin{array}{c}74.73 \pm 5.53^{*} \\
(50 \mu \mathrm{M})\end{array}$ & $\begin{array}{c}64.49 \pm 19.30 * \\
(50 \mu \mathrm{M})\end{array}$ \\
\hline & & $\begin{array}{l}\text { Olaparib (AZD-2281, trade } \\
\text { name Lynparza) }\end{array}$ & PARP1 and 2 & $1-20 \mu \mathrm{M}$ & $\begin{array}{c}41.33 \pm 8.62 \\
(10 \mu \mathrm{M})\end{array}$ & $\begin{array}{c}26.67 \pm 9.35 \\
(10 \mu \mathrm{M})\end{array}$ & $\begin{array}{c}18.89 \pm 14.45 \\
(10 \mu \mathrm{M})\end{array}$ \\
\hline & \multirow{4}{*}{ Necroptosis } & Necrostatin-1 & $\begin{array}{l}\text { Receptor-interacting protein kinase } \\
1 \text { (RIP1) }\end{array}$ & $10-250 \mu \mathrm{M}$ & $\begin{array}{c}89.21 \pm 25.81^{*} \\
\#(100 \mu \mathrm{M})\end{array}$ & $\begin{array}{c}86.95 \pm 11.86 \text { * } \\
\#(100 \mu M)\end{array}$ & $\begin{array}{c}72.97 \pm 14.32 \# \\
(100 \mu M)\end{array}$ \\
\hline & & \begin{tabular}{|l|}
$\begin{array}{l}\text { Necrostatin-1, Inactive } \\
\text { Control }\end{array}$ \\
\end{tabular} & Inactive Nec-1 analog & $10-250 \mu \mathrm{M}$ & $\begin{array}{c}28.59 \pm 11.57 \\
(100 \mu \mathrm{M})\end{array}$ & $\begin{array}{c}51.84 \pm 14.19 \\
(100 \mu \mathrm{M})\end{array}$ & $\begin{array}{c}35.52 \pm 12.83 \\
(100 \mu \mathrm{M})\end{array}$ \\
\hline & & GSK872 & RIP3 & $1-30 \mu \mathrm{M}$ & $\begin{array}{c}48.04 \pm 18.40 \\
(30 \mu \mathrm{M})\end{array}$ & $\begin{array}{c}77.80 \pm 21.81 \text { * } \\
(30 \mu \mathrm{M})\end{array}$ & $\begin{array}{c}87.21 \pm 12.38 * \\
(30 \mu \mathrm{M})\end{array}$ \\
\hline & & Necrosulfonamide & $\begin{array}{l}\text { Mixed lineage kinase domain-like } \\
\text { protein (MLKL) }\end{array}$ & $1-20 \mu \mathrm{M}$ & $\begin{array}{c}98.57 \pm 14.93 \text { * } \\
(1 \mu \mathrm{M})\end{array}$ & $\begin{array}{c}32.83 \pm 22.44 \\
(1 \mu \mathrm{M})\end{array}$ & $\begin{array}{c}11.95 \pm 2.84 \text { * } \\
(1 \mu \mathrm{M})\end{array}$ \\
\hline
\end{tabular}
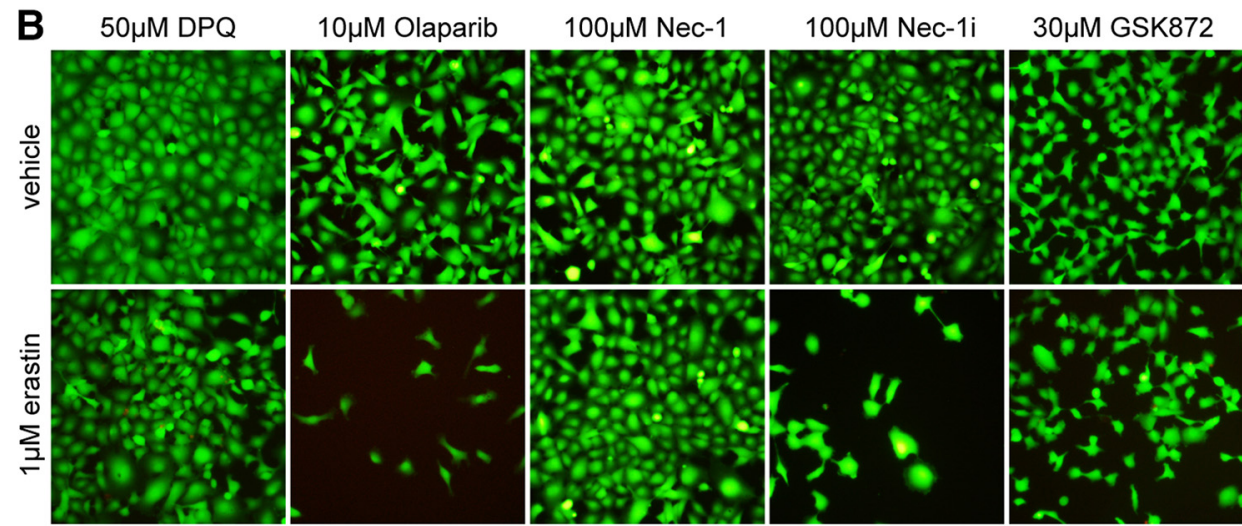

$1 \mu \mathrm{M} N S A$

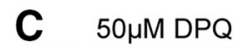

$10 \mu \mathrm{M}$ Olaparib
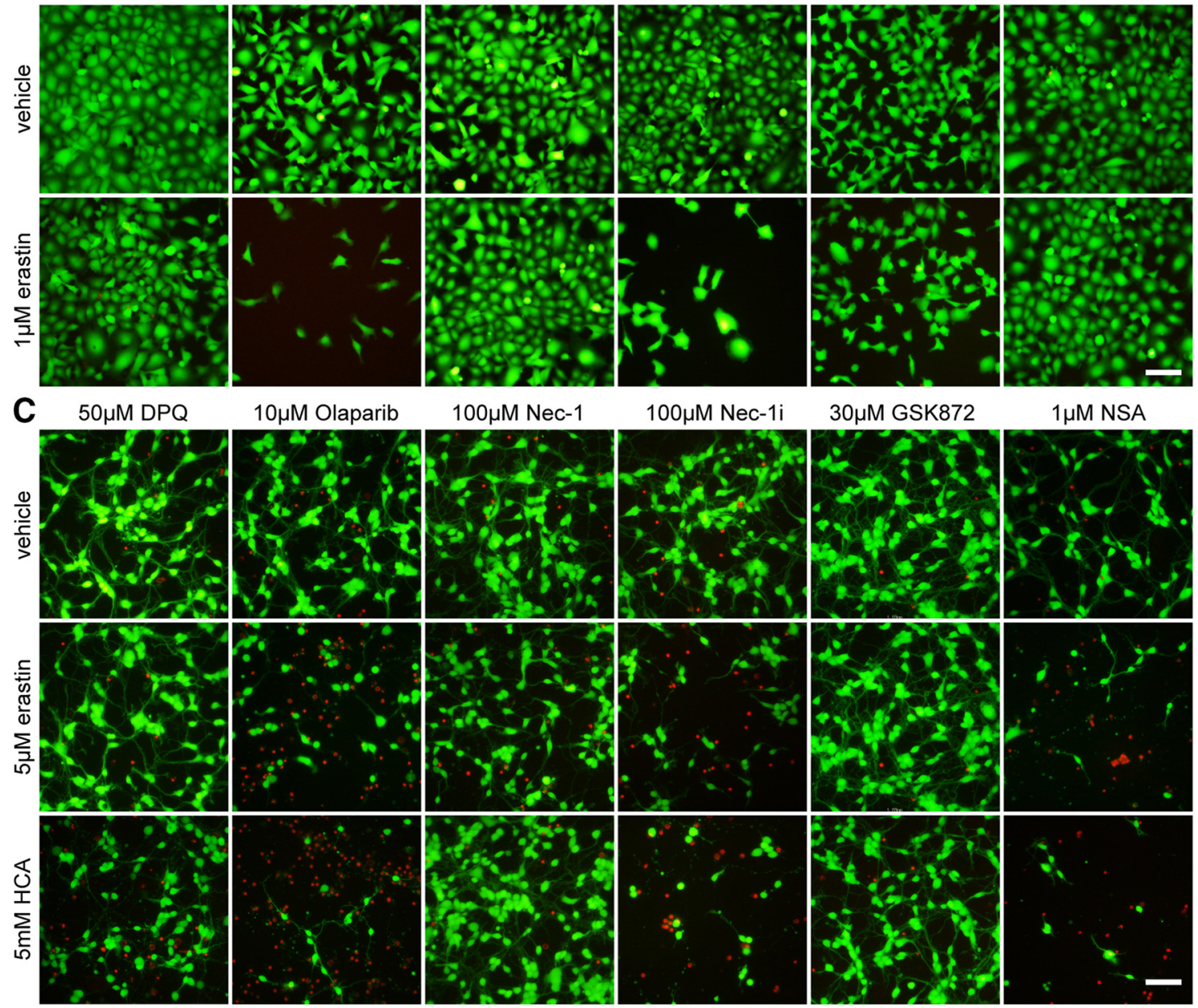

$1 \mu \mathrm{M} N S A$

Figure 6. Necroptosis inhibitors, but not parthanatos inhibitors, inhibit ferroptosis in cancer cells (HT1080) and primary cortical neurons (PCNs). $\boldsymbol{A}, \mathrm{HT} 1080$ cells were treated with $1 \mu \mathrm{M}$ erastin, PCNs with $5 \mu \mathrm{M}$ erastin or $5 \mathrm{mM}$ glutamate analog HCA and chemical inhibitors effective in necroptosis and parthanatos were examined. Numbers show mean \pm SD at representative concentration in brackets. Grayscale coding indicates the continuum from no protection in the presence of erastin (black) to maximal cell viability (white). $* p<0.05$ versus erastin or glutamate analog (HCA), \#p < 0.05 versus Necrostatin-1i. B, C, Representative live/dead staining in HT1080 cells $(\boldsymbol{B})$ and PCN $(\boldsymbol{C})$ are shown, green indicating live cells (calcein AM) and red indicating dead cells (ethidium homodimer-1). Scale bar, $50 \mu \mathrm{m}$.

sion of HDACs from class I and found that HT1080 cells and primary neurons express HDAC1, 2, and 3. Surprisingly, only HT1080 cells express HDAC8, raising the intriguing possibility that HDAC 8 expression may explain the differential effects of HDAC inhibitors between HT1080 cells and primary neurons (Fig. 13E).
To determine whether the effect is specific to HT1080 cells or applicable to other cancer cells, we evaluated whether Scriptaid protected against erastin-induced toxicity in the neuroblastoma cell line SH-SY5Y and the hepatocellular carcinoma cell line Hep3B (at the $L_{50}$ of erastin for each cell line). We found that 2.5-10 $\mu \mathrm{M}$ 
A
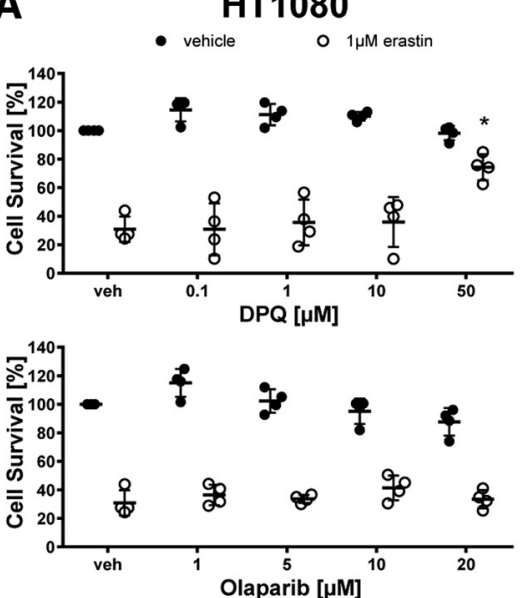

$\stackrel{*}{\circ} \stackrel{*}{\circ}$
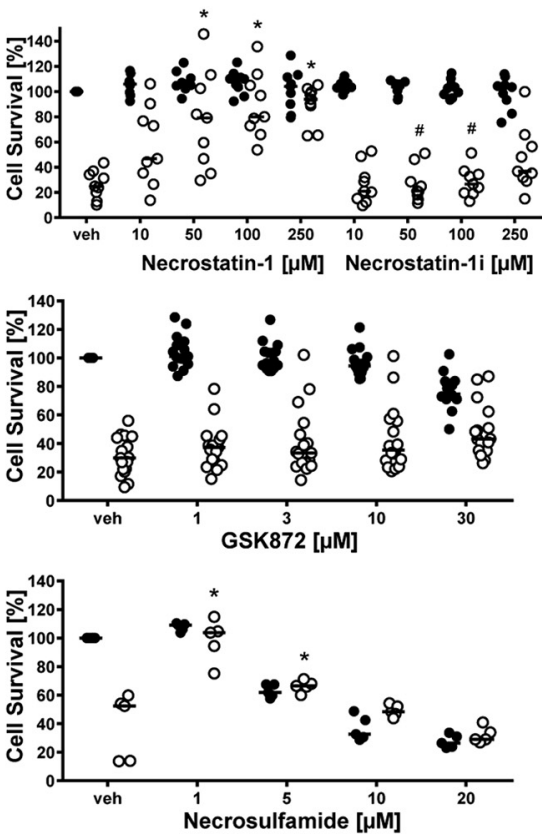

B
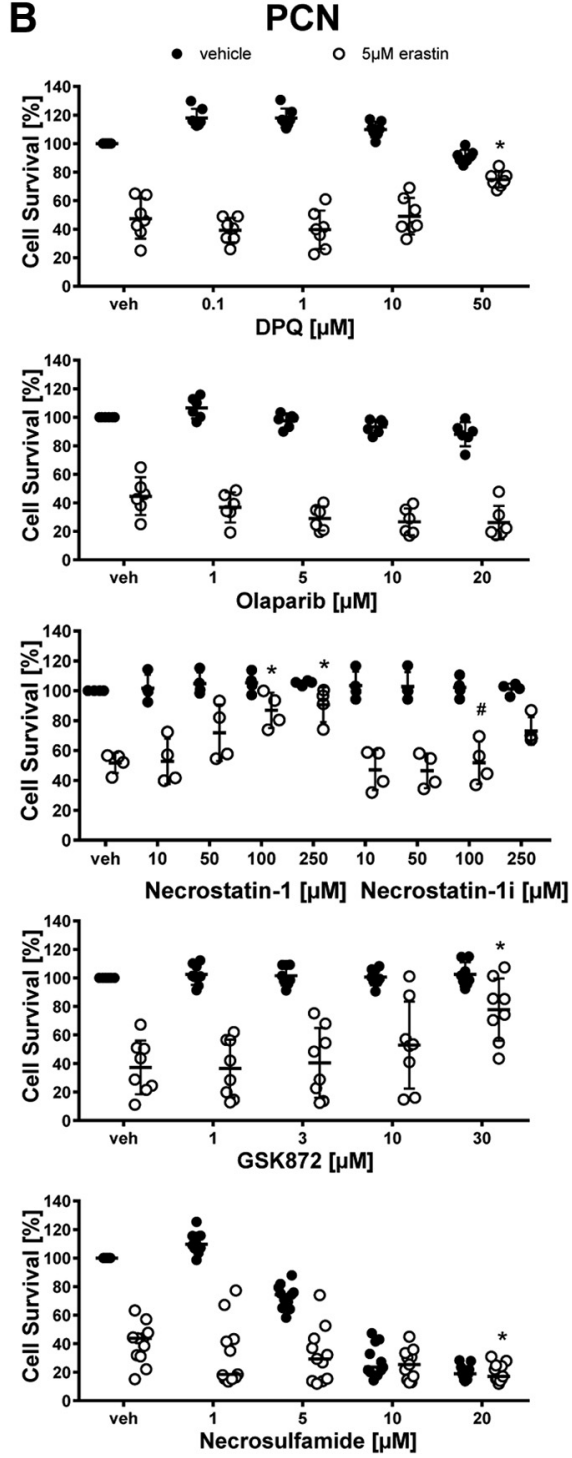
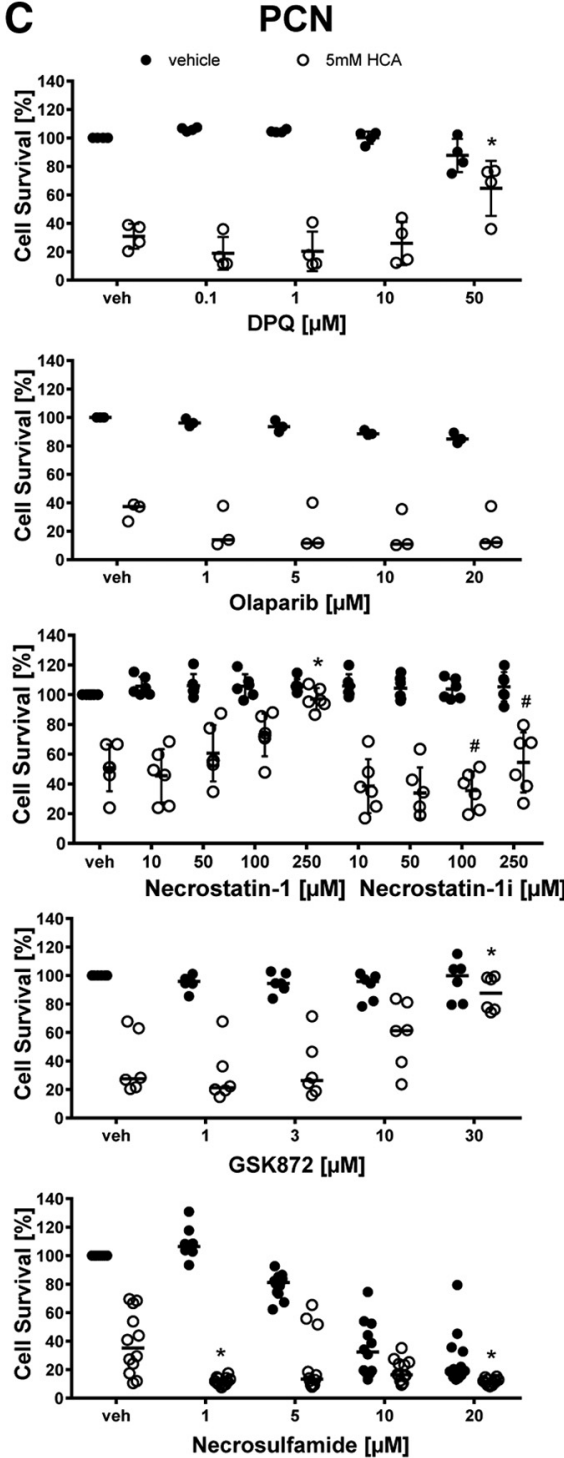

Figure 7. Dose-responses of parthanatos and necroptosis inhibitors in cancer cells (HT1080) and primary cortical neurons (PCNs). HT1080 cells were treated with $1 \mu \mathrm{M}$ erastin, PCN with $5 \mu \mathrm{M}$ erastin or $5 \mathrm{mM}$ glutamate analog HCA and chemical inhibitors effective in necroptosis and parthanatos were examined. Values represent mean \pm SD, except for Necrostatin-1 and necrosulfonamide in HT1080 cells, necrosulfonamide in PCNs treated with erastin as well as Olaparib, GSK872, and necrosulfonamide in PCNs treated with glutamate analog $(\mathrm{HCA})$ where medians are given. $* p<0.05$ versus erastin or glutamate analog $(\mathrm{HCA})$, \#p $<0.05$ versus Necrostatin-1i. For exact $p$ values refer to Figure $7-1$

Scriptaid exacerbated erastin-induced cell death in $\mathrm{SH}-$ SY5Y cells, whereas the negative control did not. However, it also decreased viability of SH-SY5Y cells without erastin treatment (Fig. 14A). In contrast, $10 \mu \mathrm{M}$ Scriptaid also enhanced erastin toxicity in Hep3B cells, although it was not toxic for the cells at that dose (Fig. 14B). Altogether, these findings suggest that HDAC inhibitors could be good adjunctive treatment for erastin or erastin-like drugs in fibrosarcomas, neuroblastoma, and hepatomas.

\section{Discussion}

The objective of this study was to understand the mechanisms by which erastin (an $\mathrm{X}_{\mathrm{c}}{ }^{-}$transporting agency inhibitor) induces death in cultured CNS neurons compared with erastin-induced death in cancer cells. The $\mathrm{X}_{\mathrm{C}}{ }^{-}$ transporting agency is a chloride-dependent transporter that exchanges cystine for glutamate. Cystine is converted intracellularly to cysteine, which is used for protein synthesis and synthesis of the versatile antioxidant glutathione. Depletion of cyst(e)ine leads to depletion of glutathione and reactive lipid species-induced death now defined as ferroptosis.

Our ultimate goal in pursuing these studies is to develop combinatorial therapeutic approaches that on the one hand enhance erastin-induced death of tumor cells, and on the other, prevent its potential toxicities in the nervous system mediated via erastin-induced neuronal death. Our results suggest that cell death pathways induced by erastin in post-mitotic cortical neurons and HT1080 fibrosarcoma are similar to each other and to oxidative glutamate toxicity in neurons (Figs. 2-9, 11). 


\section{A}

\begin{tabular}{|c|c|c|c|c|c|c|c|}
\hline \begin{tabular}{|l|} 
Cell Death \\
Mechanism
\end{tabular} & Subcategory & Cell Death Inhibitor & Target & Concentration & HT1080 Erastin & PCN Erastin & PCN HCA \\
\hline \multicolumn{5}{|c|}{ vehicle } & $30.93 \pm 13.29$ & $41.97 \pm 15.77$ & $37.10 \pm 17.41$ \\
\hline \multirow{5}{*}{ Autophagy } & \multirow{4}{*}{$\begin{array}{l}\text { Macro- } \\
\text { autophagy }\end{array}$} & 3-Methyladenine & $\begin{array}{l}\text { Phosphoinositide 3-kinase (PI3K), } \\
\text { autophagosome formation }\end{array}$ & $100-1500 \mu \mathrm{M}$ & $\begin{array}{c}69.92 \pm 28.67 \\
(1.5 \mathrm{mM})\end{array}$ & $\begin{array}{c}59.95 \pm 20.04 \\
(1.5 \mathrm{mM})\end{array}$ & $\begin{array}{c}73.75 \pm 7.59^{*} \\
(1.5 \mathrm{mM})\end{array}$ \\
\hline & & Bafilomycin A1 & Endosomal acidification & $0.001-0.1 \mu \mathrm{M}$ & $\begin{array}{c}102.23 \pm 16.14 \\
*(50 \mathrm{nM}) \\
\end{array}$ & $\begin{array}{c}50.27 \pm 11.66 \\
(50 \mathrm{nM})\end{array}$ & $\begin{array}{c}58.83 \pm 7.29 \text { * } \\
(50 \mathrm{nM})\end{array}$ \\
\hline & & $\begin{array}{l}\begin{array}{l}\text { Chloroquine diphosphate } \\
\text { salt }\end{array} \\
\end{array}$ & Lysosomal function & $0.1-10 \mu \mathrm{M}$ & $\begin{array}{c}78.20 \pm 10.44^{*} \\
(10 \mu \mathrm{M})\end{array}$ & $\begin{array}{c}28.82 \pm 12.47 \\
(10 \mu M)\end{array}$ & $\begin{array}{c}33.10 \pm 5.86 \\
(10 \mu \mathrm{M})\end{array}$ \\
\hline & & Rapamycin & $\begin{array}{l}\text { Mechanistic target of rapamycin } \\
\text { (mTOR), autophagy inducer }\end{array}$ & $0.1-5 \mu \mathrm{M}$ & $\begin{array}{c}69.05 \pm 21.32 * \\
(0.1 \mu \mathrm{M})\end{array}$ & $\begin{array}{c}76.32 \pm 11.69 \text { * } \\
(0.1 \mu \mathrm{M})\end{array}$ & $\begin{array}{c}85.81 \pm 11.59 \text { * } \\
(0.1 \mu \mathrm{M})\end{array}$ \\
\hline & Mitophagy & $\begin{array}{l}\text { Mitochondrial division } \\
\text { inhibitor } 1\end{array}$ & $\begin{array}{l}\text { GTPase activity in dynamin-related } \\
\text { protein Drp-1, abnormal mitophagy }\end{array}$ & $0.1-100 \mu \mathrm{M}$ & $\begin{array}{c}22.90 \pm 4.37 \\
(100 \mu \mathrm{M})\end{array}$ & $\begin{array}{c}75.50 \pm 23.57 \\
(100 \mu \mathrm{M})\end{array}$ & $\begin{array}{c}65.41 \pm 18.30 \\
(100 \mu \mathrm{M})\end{array}$ \\
\hline
\end{tabular}

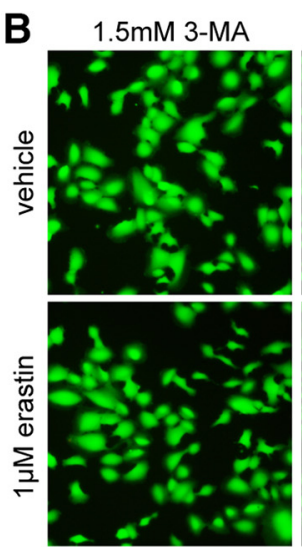

C
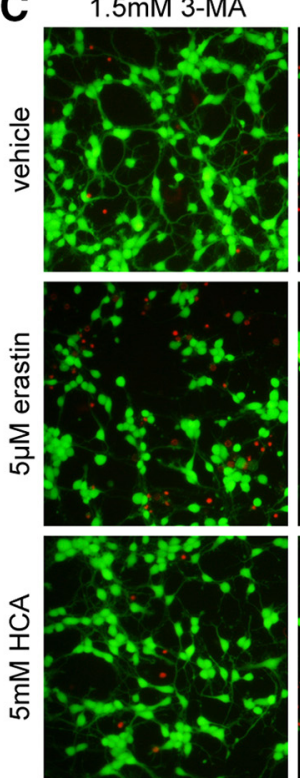

50nM BafA1

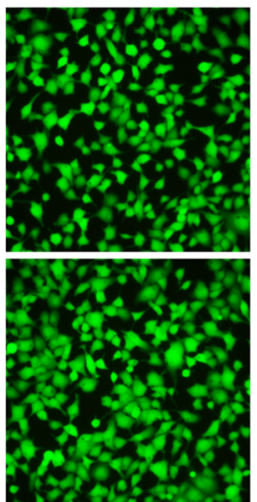

50nM BafA1

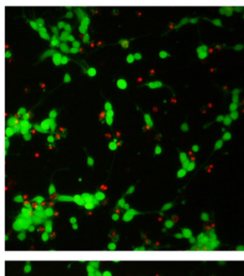

$10 \mu \mathrm{M}$ Chloroquine
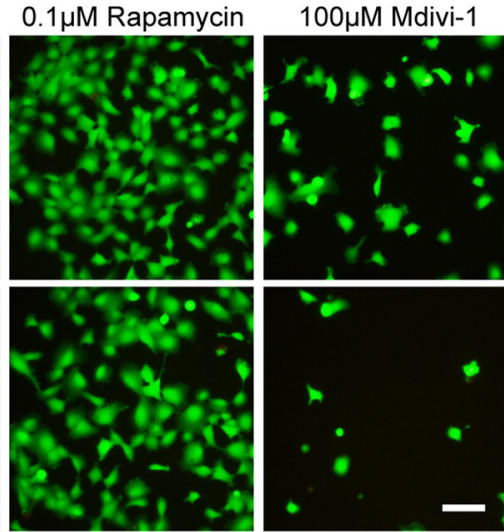

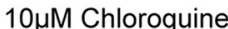
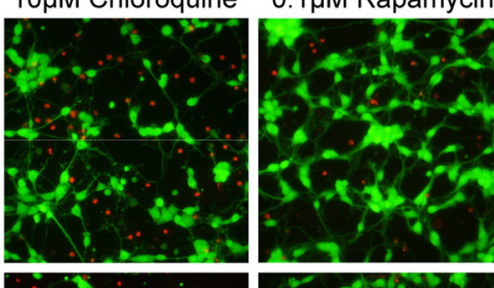

100uM Mdivi-1
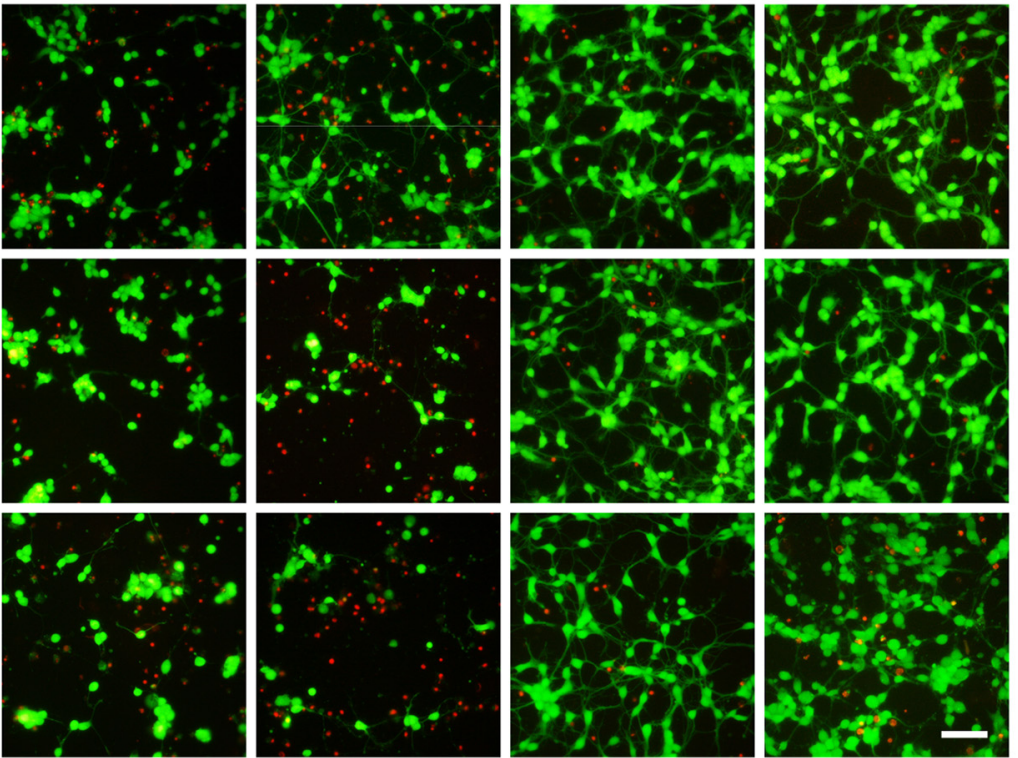

Figure 8. Autophagy inhibitors inhibit ferroptosis in cancer cells (HT1080) and primary cortical neurons (PCNs). A, HT1080 cells were treated with $1 \mu \mathrm{M}$ erastin, PCN with $5 \mu \mathrm{M}$ erastin or $5 \mathrm{mM}$ glutamate analog HCA and chemical inhibitors effective in autophagy were examined. Numbers show mean \pm SD at representative concentration in brackets. Grayscale coding indicates the continuum from no protection in the presence of erastin (black) to maximal cell viability (white). $* p<0.05$ versus erastin or glutamate analog (HCA). $\boldsymbol{B}, \boldsymbol{C}$, Representative live/dead staining in HT1080 cells $(\boldsymbol{B})$ and PCN $(\boldsymbol{C})$ are shown, green indicating live cells (calcein AM) and red indicating dead cells (ethidium homodimer-1). Scale bar, $50 \mu \mathrm{m}$.

Both glutamate and erastin can inhibit the system $\mathrm{X}_{\mathrm{c}}^{-}$to induce death in immature neurons where functional, ionotropic glutamate receptors are not expressed (Murphy et al., 1989; Ratan et al., 1994a, b,). We leveraged prior studies of cystine deprivation in neurons to identify HDAC inhibitors as agents that enhance the chemotherapyinduced ferroptosis of tumors while inhibiting ferroptosis in neurons. These findings suggest a combinatorial approach to cancer chemotherapy (erastin plus a class I HDAC inhibitor) designed to maximize tumor cell death 
A
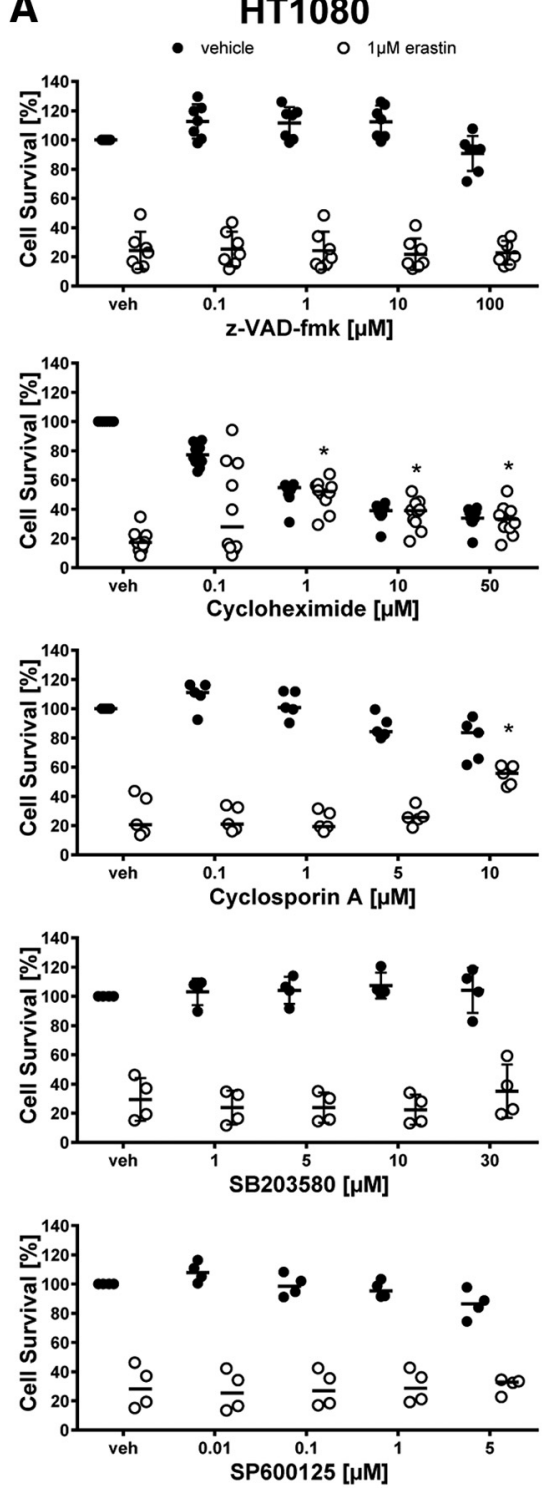

B
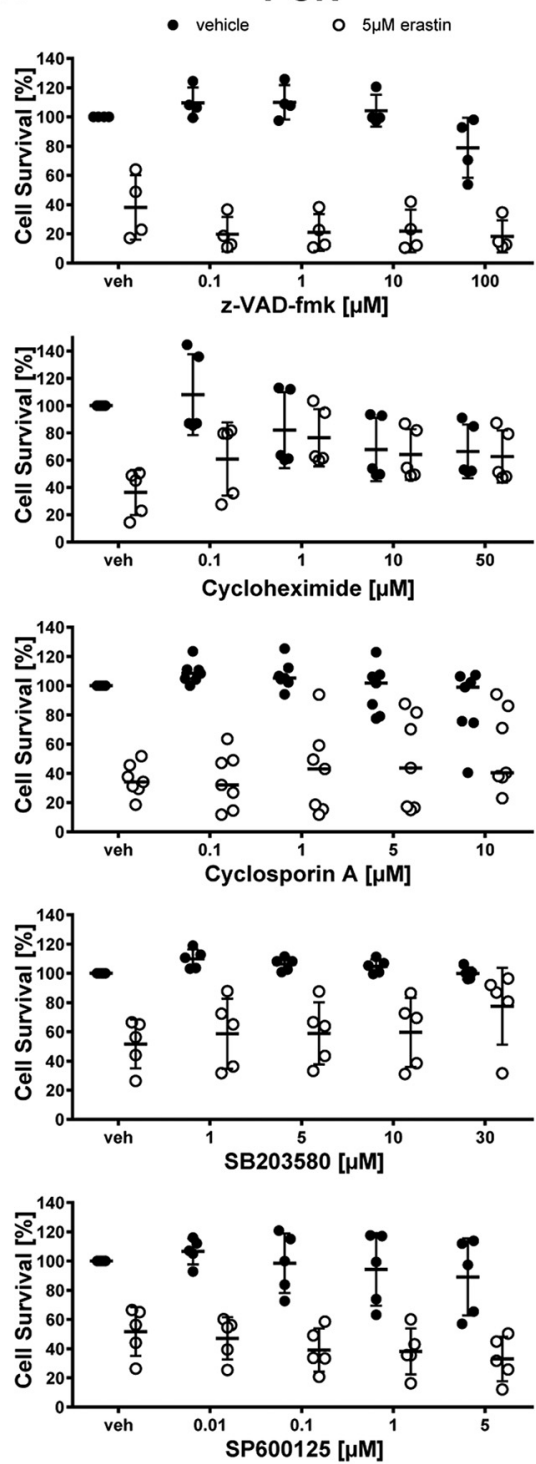
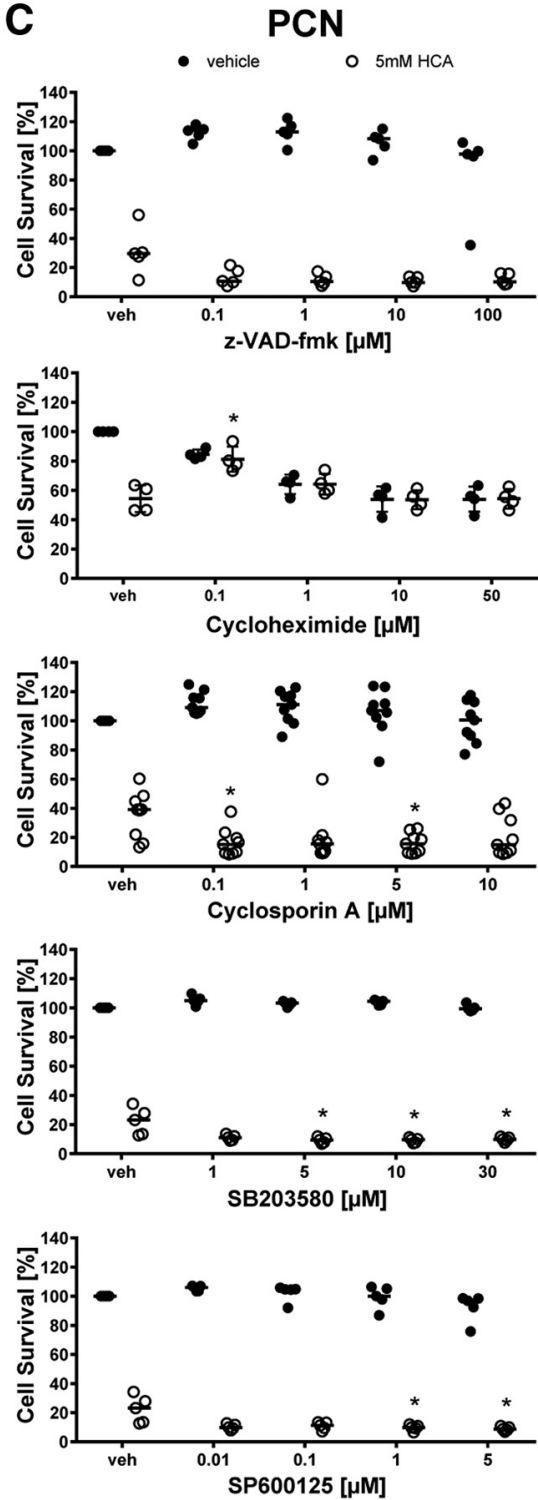

Figure 9. Dose-responses of autophagy inhibitors in cancer cells (HT1080) and primary cortical neurons (PCNs). HT1080 cells were treated with $1 \mu \mathrm{M}$ erastin, PCNs with $5 \mu \mathrm{M}$ erastin or $5 \mathrm{mM}$ glutamate analog HCA and chemical inhibitors effective in autophagy were examined. Values represent mean $\pm \mathrm{SD}$, except for 3-methyladenine, Bafilomycin $\mathrm{A} 1$, and Chloroquine in PCNs treated with erastin as well as all inhibitors in PCNs treated with glutamate analog (HCA) where medians are given. $* p<0.05$ versus erastin or glutamate analog (HCA). For exact $p$ values refer to Figure 9-1.

and minimize neuronal toxicity. Our studies also identified agents that prevent ferroptotic death in cancer cells and neurons that would not be good candidates for cancer treatment (e.g., HIF PHD inhibitors, transglutaminase inhibitors, and the gene selective Sp1 inhibitor Mithramycin).

Our studies systemically evaluated whether erastininduced ferroptosis in cancer cells occurs via mechanisms that are similar to or distinct from those induced by erastin in primary neurons. We found that erastin-induced toxicity in tumor cells can be abolished not only by previously published ferroptosis inhibitors (Dixon et al., 2012; Figs. 2, 3) but also by inhibitors of necroptosis (Figs. 6-7, 10) and autophagy (Figs. 8, 9) when erastin was used at a toxicologically relevant dose.
With respect to autophagy, Torii et al. (2016) previously reported that Bafilomycin A1, a vacuolar ATPase inhibitor that prevents endosomal acidification, abolished cell death induced by erastin (all doses tested) as well as another inducer of ferroptosis, RSL3, in HT1080 and Calu-1 cells. Similarly, knock-out of autophagy-related genes Atg5 and Atg7 in mouse embryonic fibroblasts and knockdown in HT1080 cells partially inhibited erastininduced cell death (Hou et al., 2016). These data suggest that cyst(e)ine deprivation may not only be interpreted by the cell as uncompensated redox but also nutrient dyshomeostasis, thereby triggering multiple parallel pathways (e.g., reactive lipid species, autophagy) that collectively elevate the threshold of the cell toward cell demise (Zille et al., 2017). 
A

\begin{tabular}{|r|c|c|c|c|c|c|c|c|}
\hline$[\mathrm{h}]$ & 0 & 2 & 4 & 8 & 12 & 12 & 8 & 8 \\
\hline $100 \mu \mathrm{M}$ Nec-1 & - & - & - & - & - & + & - & + \\
\hline
\end{tabular}
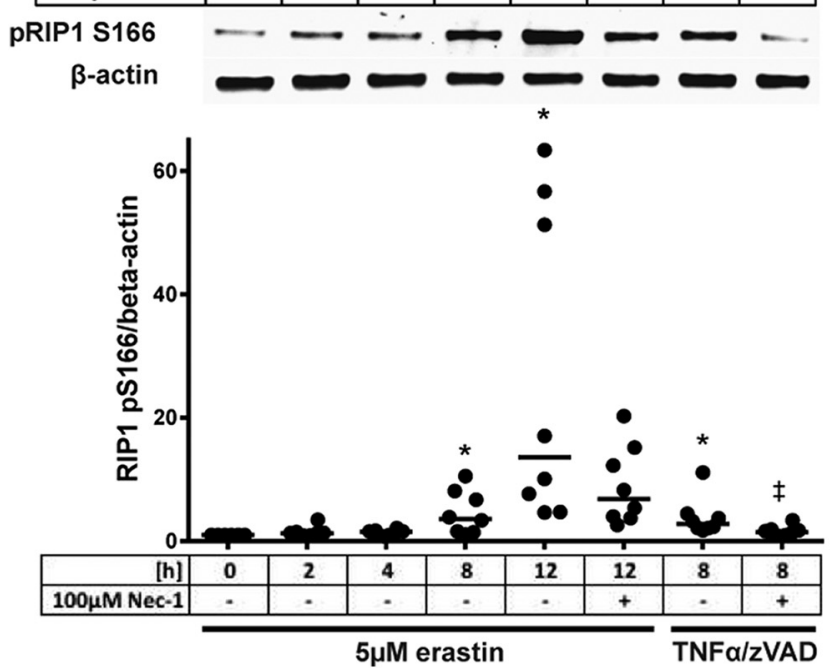

B

\begin{tabular}{|c|c|c|c|c|c|c|c|c|}
\hline & \multicolumn{6}{|c|}{$5 \mathrm{mM}$ HCA } & \multicolumn{2}{|c|}{ TNF $\alpha / z V A D$} \\
\hline [h] & 0 & 2 & 4 & 8 & 12 & 12 & 8 & 8 \\
\hline $100 \mu \mathrm{M}$ Nec-1 & - & - & - & - & - & + & - & + \\
\hline
\end{tabular}

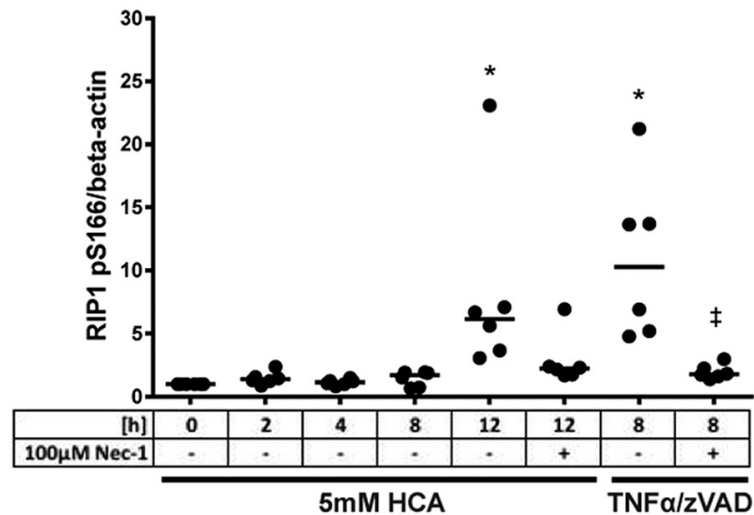

Figure 10. Ferroptosis inducer erastin and glutamate analog HCA activate necroptotic machinery. Levels of phospho-RIP1 (normalized to $\beta$-actin) were measured in HT22 cells exposed to erastin $(\boldsymbol{A})$, glutamate analog (HCA; $\boldsymbol{B})$ or $100 \mathrm{ng} / \mathrm{ml} \mathrm{TNF} \alpha+5 \mu \mathrm{M}$ z-VAD-fmk for $8 \mathrm{~h}$ (positive control in $\boldsymbol{A}$ and $\boldsymbol{B}$ ). Necrostatin-1 served as confirmation for specificity of RIP1 kinase activity. Values represent median. $* p<0.05$ versus 0 h erastin or glutamate analog (HCA), $\neq p<0.05$ versus $8 \mathrm{~h}$ TNF $\alpha / z$ VAD. For exact $p$ values refer to Figure $10-1$.

A

\begin{tabular}{|c|c|c|c|c|c|c|c|}
\hline Criterion & & 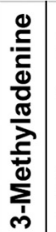 & 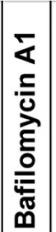 & 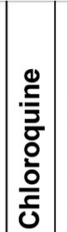 & 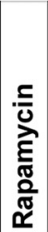 & $\frac{\bar{T}}{\frac{\bar{z}}{2}}$ & 总 \\
\hline \multicolumn{2}{|c|}{ Ferroptosis (Dixon et al.) } & - & - & - & & & - \\
\hline \multicolumn{2}{|c|}{ Erastin HT1080 } & - & + & + & + & - & - \\
\hline \multicolumn{2}{|l|}{ Erastin PCN } & - & - & - & + & - & - \\
\hline \multicolumn{2}{|c|}{ HCA PCN } & + & + & - & + & - & - \\
\hline \multicolumn{2}{|c|}{ Hemin Toxicity (Zille et al.) } & - & - & - & - & - & - \\
\hline $2 \times 2$ contingency table & $\begin{array}{l}\text { Meets } \\
\text { Criterion }\end{array}$ & & $\begin{array}{r}\text { Does } \\
\text { Me } \\
\text { Crite }\end{array}$ & $\begin{array}{l}\text { s Not } \\
\text { eet } \\
\text { erion }\end{array}$ & & Tota & \\
\hline Ferroptosis (Dixon et al.) & 7 & & & 6 & & & 13 \\
\hline Erastin HT1080 & 11 & & 2 & 2 & & & 13 \\
\hline Total & 18 & & 8 & 8 & & & 26 \\
\hline
\end{tabular}

Fisher's exact test, two-tailed $\mathrm{p}=0.202$

\begin{tabular}{|l|c|c|r|}
\hline $2 \times 2$ contingency table & $\begin{array}{c}\text { Meets } \\
\text { Criterion }\end{array}$ & $\begin{array}{c}\text { Does Not } \\
\text { Meet } \\
\text { Criterion }\end{array}$ & Total \\
\hline Erastin HT1080 & 14 & 7 & 21 \\
\hline Erastin PCN & 10 & 11 & 21 \\
\hline Total & 24 & 18 & 42 \\
\hline
\end{tabular}

Fisher's exact test, two-tailed $\mathrm{p}=0.350$

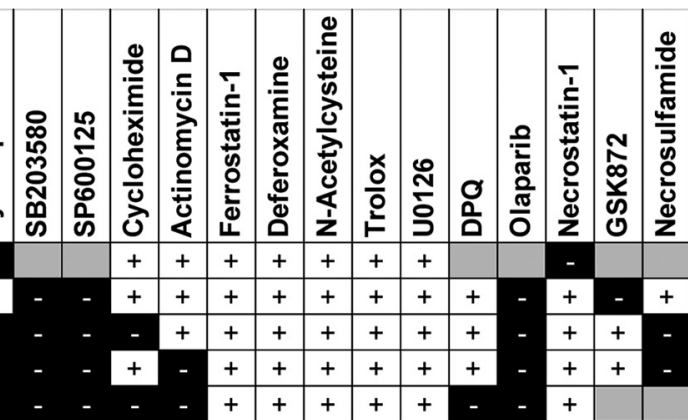

\begin{tabular}{|l|c|c|r|}
\hline $2 \times 2$ contingency table & $\begin{array}{c}\text { Meets } \\
\text { Criterion }\end{array}$ & $\begin{array}{c}\text { Does Not } \\
\text { Meet } \\
\text { Criterion }\end{array}$ & Total \\
\hline Erastin PCN & 10 & 11 & 21 \\
\hline HCA PCN & 12 & 9 & 21 \\
\hline Total & 22 & 20 & 42 \\
\hline
\end{tabular}

Fisher's exact test, two-tailed $\mathrm{p}=\mathbf{0 . 7 5 8}$

\begin{tabular}{|l|c|c|r|}
\hline 2x2 contingency table & $\begin{array}{c}\text { Meets } \\
\text { Criterion }\end{array}$ & $\begin{array}{c}\text { Does Not } \\
\text { Meet } \\
\text { Criterion }\end{array}$ & Total \\
\hline Erastin HT1080 & 14 & 7 & 21 \\
\hline HCA PCN & 12 & 9 & 21 \\
\hline Total & 26 & 16 & 42 \\
\hline
\end{tabular}

Fisher's exact test, two-tailed $\mathbf{p}=\mathbf{0 . 7 5 1}$

Figure 11. Systematic pharmacologic characterization reveals inhibitors of autophagy and necroptosis abrogate ferroptosis in cancer cells (HT1080) and primary cortical neurons (PCNs). A, Comparison of protection profile of chemical inhibitors between operationally defined ferroptosis (Dixon et al., 2012, 2014), erastin-induced toxicity in HT1080 cells at toxicologically meaningful dose, erastin and glutamate analog (HCA) in PCNs and previously published hemin toxicity in PCNs (Zille et al., 2017). B. Statistical analysis of profile of chemical inhibitors between operationally defined ferroptosis and erastin-induced toxicity in HT1080 revealed that they are statistically similar, but major differences (i.e., protection by inhibitors of autophagy and necroptosis) exist. Statistical analysis showed no difference between erastin treatment in PCNs and HT1080 cells, erastin- and glutamate analog (HCA)-treated PCNs or erastin in HT1080 cells and HCA in PCNs. 


\begin{tabular}{|c|c|c|c|c|c|}
\hline Cell Death Inhibitor & Target & Concentrations & HT1080 Erastin & $\begin{array}{l}\text { Published HCA or } \\
\text { Glutamate in PCN }\end{array}$ & References of published work \\
\hline \multicolumn{3}{|c|}{ vehicle } & $34.23 \pm 12.46$ & $27.86 \pm 6.12$ & \\
\hline Adaptaquin & $\begin{array}{l}\text { Hypoxia-inducible factor (HIF) prolyl } \\
\text { hydroxylase domain-containing (PHD) }\end{array}$ & $0.01-1 \mu \mathrm{M}$ & $\begin{array}{l}101.56 \pm 28.55 \text { * } \\
(0.5 \mu \mathrm{M})\end{array}$ & $\begin{array}{l}89.10 \pm 7.56 \text { * } \\
(0.5 \mu \mathrm{M})\end{array}$ & $\begin{array}{l}\text { Karuppagounder et al., Sci Transl Med, } \\
2016\end{array}$ \\
\hline Mithramycin & Sp1 & $0.05-0.3 \mu \mathrm{M}$ & $\begin{array}{l}79.92 \pm 17.35 * \\
\quad(50 \mathrm{nM})\end{array}$ & $\begin{array}{l}71.67 \pm 7.57^{*} \\
\quad(200 \mathrm{nM})\end{array}$ & $\begin{array}{l}\text { Chatterjee et al., Annal Neurol, } 2001 \\
\text { Ferrante et al., J Neurosci, } 2004 \\
\text { Sleiman et al., J Neurosci, } 2011 \\
\text { Sleiman et al., Pharmaceuticals, } 2011\end{array}$ \\
\hline Cystamine & \multirow{3}{*}{ Transglutaminase } & $0.1-100 \mu \mathrm{M}$ & $\begin{array}{c}96.22 \pm 17.75^{*} \\
(10 \mu \mathrm{M})\end{array}$ & $\begin{array}{c}103.18 \pm 0.86^{*} \\
(10 \mu \mathrm{M})\end{array}$ & \multirow{3}{*}{ Basso et al., J Neurosci, 2012} \\
\hline B003 & & $25-200 \mu \mathrm{M}$ & $\begin{array}{c}87.79 \pm 11.82 * \\
(200 \mu \mathrm{M})\end{array}$ & $\begin{array}{c}98.83 \pm 6.70^{*} \\
(200 \mu \mathrm{M})\end{array}$ & \\
\hline D004 & & $12.5-100 \mu \mathrm{M}$ & $\begin{array}{c}45.82 \pm 18.00 \\
(100 \mu \mathrm{M})\end{array}$ & $\begin{array}{c}78.63 \pm 29.17^{*} \\
(100 \mu \mathrm{M}) \\
\end{array}$ & \\
\hline Apicidin & \multirow{5}{*}{ Histone deacetylase } & $0.01-0.5 \mu \mathrm{M}$ & $\begin{array}{l}11.82 \pm 4.35^{*} \\
\quad(100 \mathrm{nM})\end{array}$ & $\begin{array}{c}79.36 \pm 10.17^{*} \\
(100 \mathrm{nM})\end{array}$ & \multirow{3}{*}{$\begin{array}{l}\text { Ryu et al., PNAS, } 2003 \\
\text { Sleiman et al., J Neurosci, } 2014 \\
\text { Sleiman et al., Pharmaceuticals, } 2011\end{array}$} \\
\hline Butyrate & & $0.1-10 \mathrm{mM}$ & $\begin{array}{l}16.71 \pm 8.20 * \\
(5 \mathrm{mM})\end{array}$ & $\begin{array}{c}76.84 \pm 1.67^{*} \\
(5 \mathrm{mM})\end{array}$ & \\
\hline MS-275 & & $0.5-5 \mu \mathrm{M}$ & $\begin{array}{c}22.32 \pm 13.24 * \\
(1 \mu \mathrm{M})\end{array}$ & $\begin{array}{c}64.17 \pm 0.84^{*} \\
(100 \mathrm{nM}) \\
\end{array}$ & \\
\hline Scriptaid & & $1-10 \mu \mathrm{M}$ & $\begin{array}{c}28.29 \pm 6.75 \\
(5 \mu \mathrm{M})\end{array}$ & $\begin{array}{l}70.00 \pm 5.00^{*} \\
(6.13 \mu \mathrm{M})\end{array}$ & \multirow{2}{*}{ Langley et al., J Neurosci, 2008} \\
\hline $\begin{array}{l}\text { Nullscript (Scriptaid } \\
\text { negative control) }\end{array}$ & & $1-10 \mu \mathrm{M}$ & $\begin{array}{c}24.29 \pm 8.29 \\
(5 \mu \mathrm{M})\end{array}$ & $\begin{array}{c}27.00 \pm 0.96 \\
(6.13 \mu \mathrm{M})\end{array}$ & \\
\hline
\end{tabular}
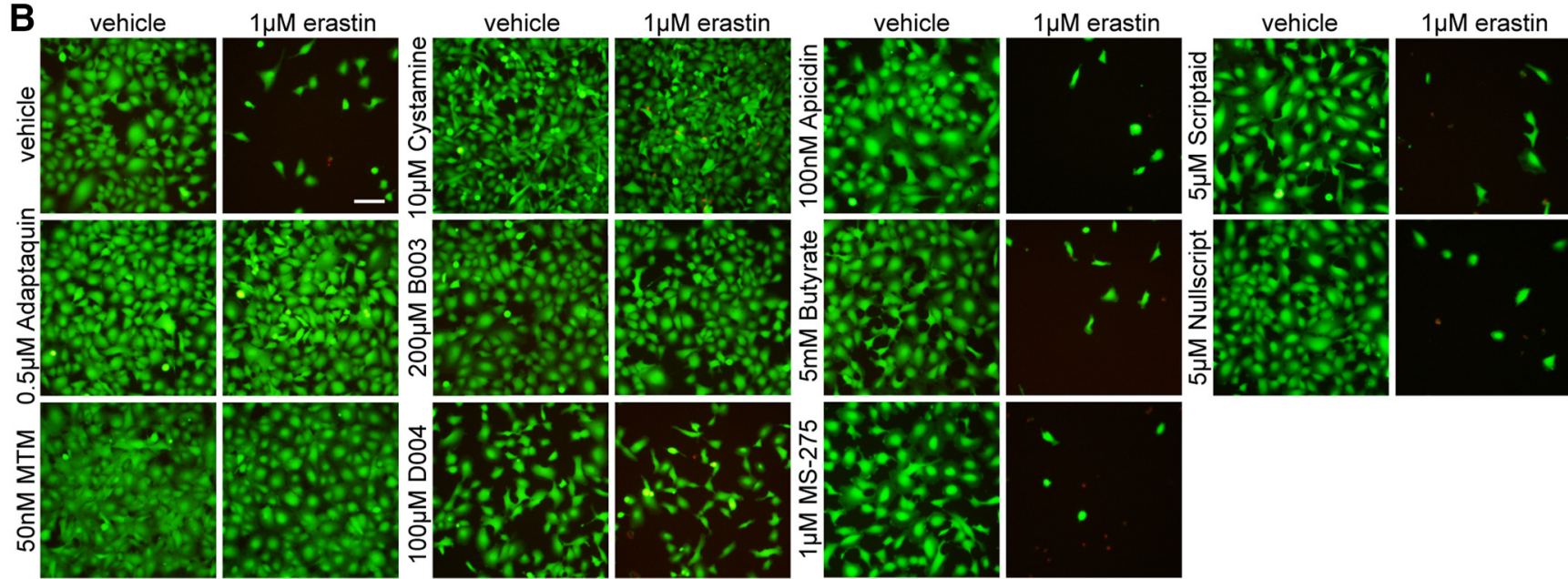

Figure 12. Do inhibitors of HCA-induced death in neurons prevent ferroptosis in cancer cells? $\boldsymbol{A}$, HT1080 cells were treated with 1 $\mu \mathrm{M}$ erastin $\left(\mathrm{LD}_{50}\right)$ and chemical inhibitors effective in glutamate analog (HCA)-induced neuronal toxicity (values from published work and references indicated in last 2 columns) were examined. Numbers show mean \pm SD at representative concentration in brackets. Grayscale coding indicates the continuum from no protection in the presence of erastin (black) to maximal cell viability (white). $* p<$ 0.05 versus erastin, \#p $<0.05$ versus Nullscript (negative control). $\boldsymbol{B}$, Representative live/dead staining are shown, green indicating live cells (calcein AM) and red indicating dead cells (ethidium homodimer-1). Scale bar, $50 \mu \mathrm{m}$.

With respect to necroptosis, Yu and colleagues demonstrated that Necrostatin-1 as well as knockdown of RIP3 abrogated erastin toxicity in acute myeloid leukemia cells (Yu et al., 2015). Interestingly, MLKL deficiency increased sensitivity to ferroptosis stimuli in mouse embryonic fibroblast. In turn, the loss of acyl-CoA synthetase long-chain family member 4 , that suppresses ferroptosis by limiting the membrane-resident pool of oxidationsensitive fatty acids, predisposed cells to necroptosis (Muller et al., 2017). This suggests that necroptosis and ferroptosis are differentially regulated cell death pathways. It has previously been demonstrated that ferroptosis and necroptosis are recruited independently in neurons exposed to intracerebral hemorrhage and that they may then converge at a yet to be identified common denominator leading to a necrotic morphology (Zille et al.,
2017). Here, we provide evidence that erastin is able to recruit the necroptotic machinery in diverse cell types (Fig. 10).

However, HT1080 fibrosarcoma cells have been reported not to express RIP3 (de Almagro et al., 2017) and were therefore not responsive to the inhibition by GSK872 in our study. This is interesting, because Necrostatin-1 and necrosulfonamide abolished erastin-induced toxicity. Although the activation of RIP1, RIP3, and MLKL have been considered to be indispensable for necroptosis, recent studies suggest possible necroptosis-independent roles of each protein, including the induction of apoptosis and the inflammasome (Mandal et al., 2014; Berger et al., 2016). In addition to the mentioned differences in the expression and post-translational regulation of necrosome complex proteins and caspase- 8 in various cell 
A
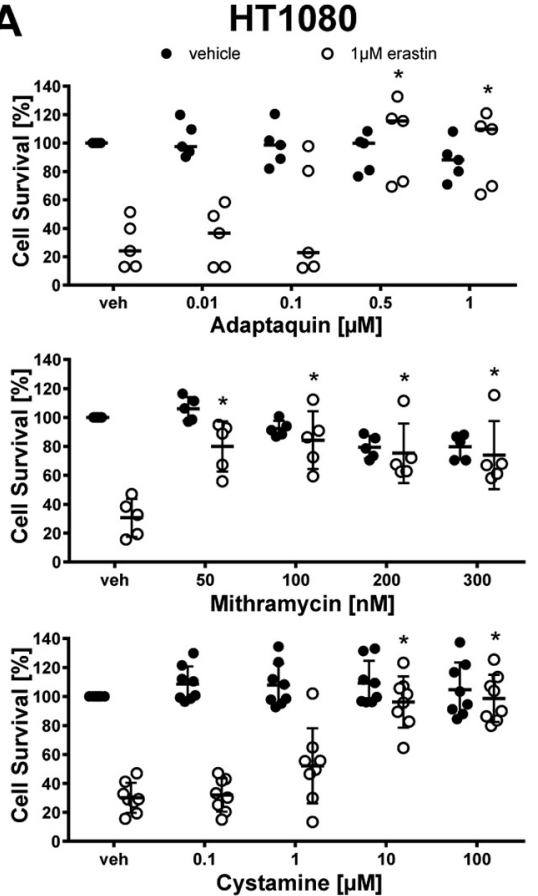

B
HT1080

- vehicle $\mathrm{O} 1 \mu \mathrm{M}$ erastin
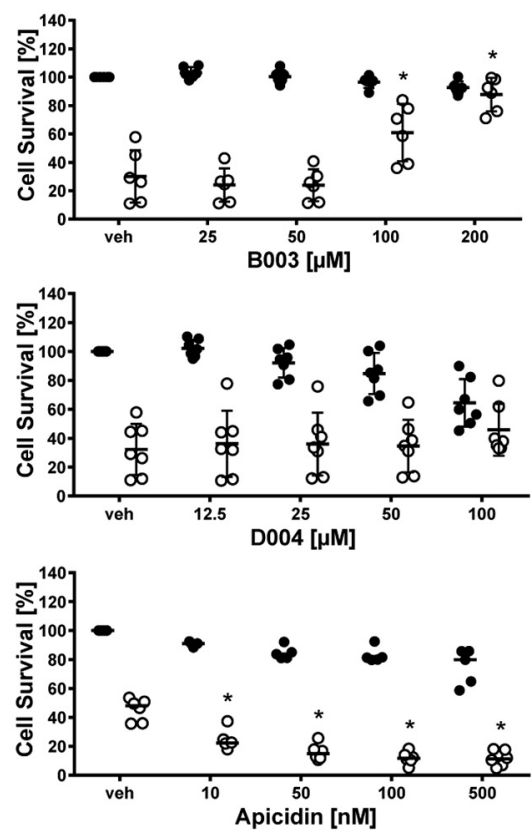

HT1080

- vehicle $\quad 1 \mu \mathrm{M}$ erastin
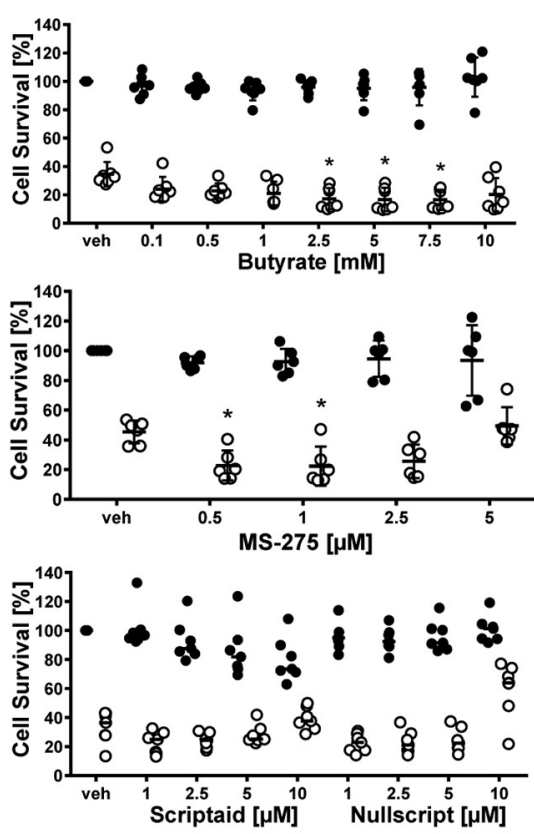

PCN

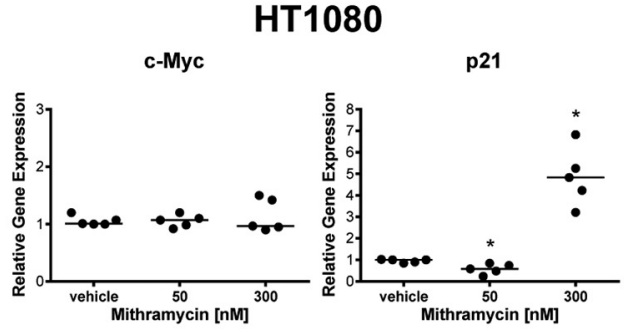

C

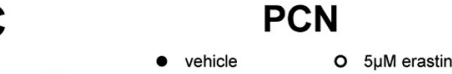

D

HT1080

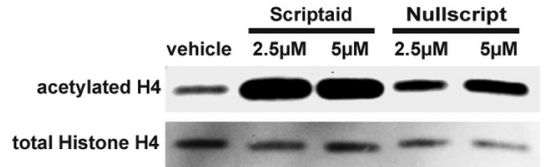

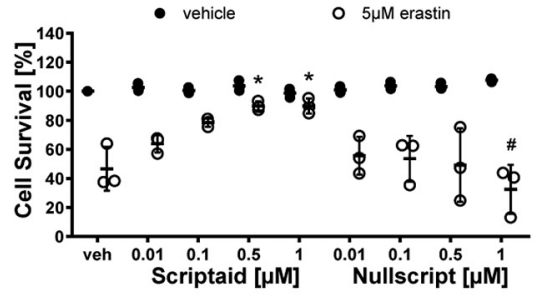

E

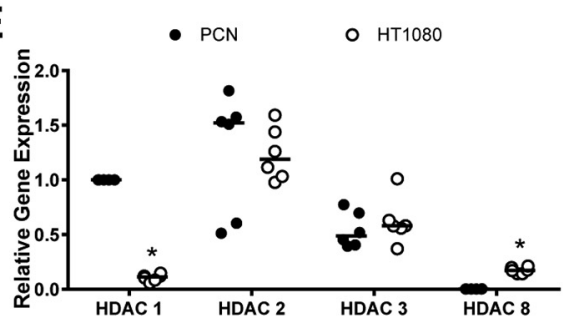

Figure 13. Protective effect of inhibitors of neuronal toxicity of glutamate analog (HCA) in erastin-induced death in HT1080 cells. $\boldsymbol{A}$, Dose-responses of chemical inhibitors effective in HCA-induced neuronal toxicity. Values represent mean \pm SD, except for Adaptaquin, Apicidin, and Scriptaid, where medians are given. $* p<0.05$ versus erastin. B, Gene expression levels of Mithramycin target genes c-Myc and p21 were assessed in HT1080 cells exposed to 50 or $300 \mathrm{~nm}$ Mithramycin. Values represent medians. $* p=$ 0.009 versus vehicle. $\boldsymbol{C}$, Dose-responses of Scriptaid and Nullscript (negative control) in erastin-induced cell death in primary cortical neurons (PCNs). Values represent mean $\pm \mathrm{SD}, * p<0.05$ versus erastin, $\# p<0.05$ versus Nullscript (negative control). $\boldsymbol{D}$, Protein levels of acetylated and total histone H4 were assessed in HT1080 cells exposed to Scriptaid or its inactive analog Nullscript. E, Gene expression of HDACs from class I in PCNs versus HT1080 cells. Values represent medians. $* p<0.0125$ versus PCNs. For exact $p$ values refer to Figures 13-1, 13-2, 13-3, and 13-4.

types (Newton et al., 2016; de Almagro et al., 2017), they also differ in their sensitivity to erastin (Yang et al., 2014; Yu et al., 2015). Thus, the relative contribution of ferroptosis and necroptosis during regulated cell death needs further investigation, especially with respect to cell type, tissue, and disease. This will greatly influence the effectiveness and toxicity of chosen chemotherapeutic approaches.
To investigate the ability of erastin to cause unwanted toxicities in the nervous system, we examined whether erastin engages a similar pattern of cell death signaling in primary neurons compared with HT1080 cells. Indeed, the exposure to erastin led to the death of primary cortical neurons, which was reversed by a statistically similar profile (Fig. 11) of inhibitors of cell death, including autophagy (Figs. 8, 9), ferroptosis (Figs. 2, 3), and necrop- 

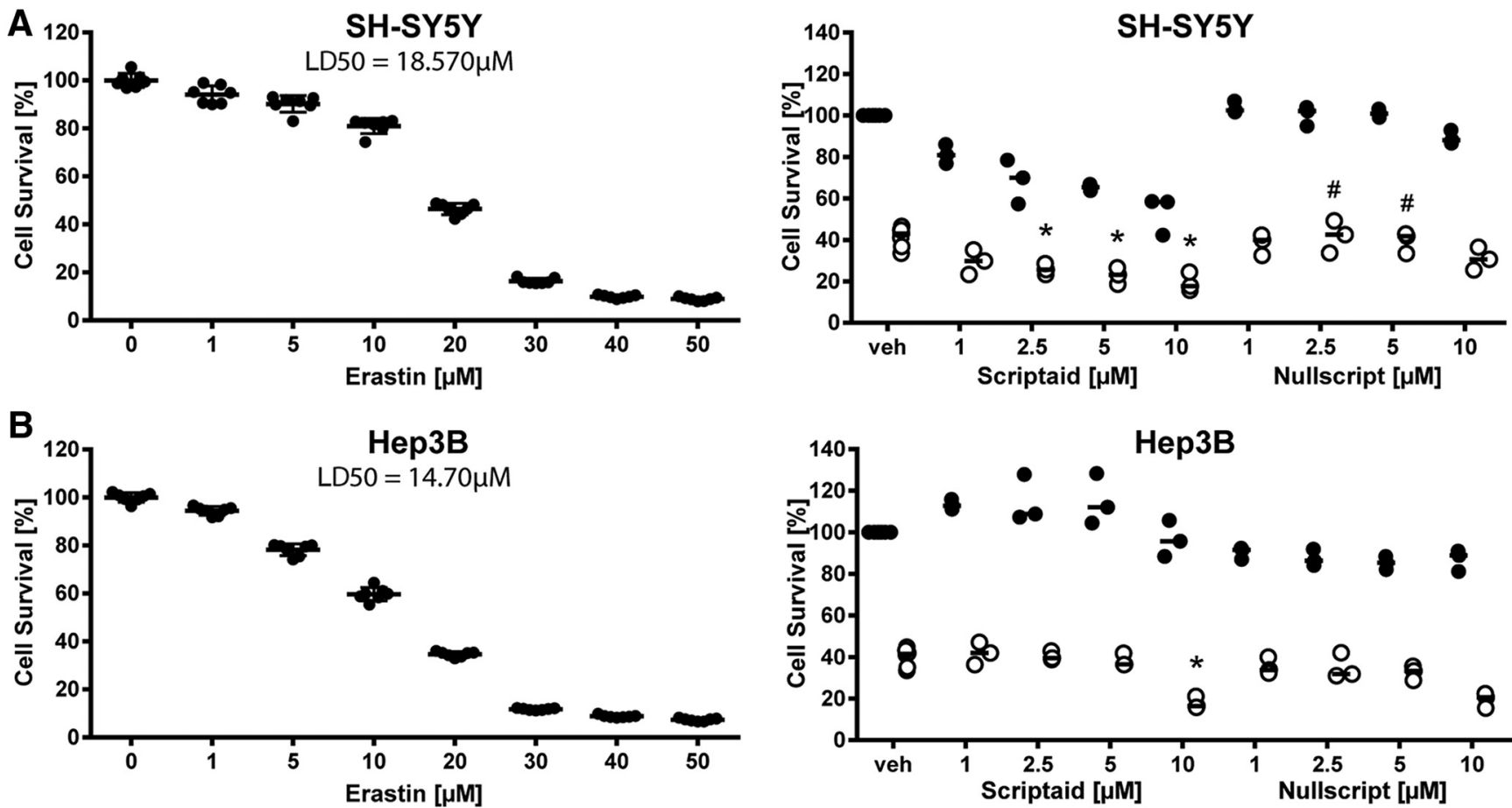

Figure 14. Dose-responses of erastin and Scriptaid in SH-SY5Y neuroblastoma and Hep3B hepatocellular carcinoma cells. SH-SY5Y $(\boldsymbol{A})$ and Hep3B cells $(\boldsymbol{B})$ were treated with increasing dose of erastin to determine the $\mathrm{LD}_{50}$ that was subsequently used to assess whether Scriptaid exacerbated erastin-induced toxicity. Nullscript was used as structural analog (negative control). Values represent mean $\pm \mathrm{SD}$. $* p<0.05$ versus erastin, $\# p<0.05$ versus Nullscript. For exact $p$ values refer to Figure 14-1.

tosis (Figs. 6, 7, 10). We also found that in an established glutathione depletion model involving non-receptormediated toxicity by glutamate (HCA), a panoply of chemical inhibitors also blocked erastin-induced death (Figs. 2-9, 11). In addition, both erastin- and glutamate (HCA)induced ferroptosis recruited the necrosome by activating RIP1 (Fig. 10). This is further substantiated by recent findings of Neitemeier et al. (2017) who demonstrated mitochondrial dysfunction in glutamate and erastin toxicity in HT22 hippocampal neuroblast cells, and this effect was abolished by the loss of $\mathrm{BH} 3$ Interacting Domain Death Agonist (BID).

Finally, we sought to demonstrate whether the knowledge about glutamate analog (HCA)-induced ferroptosis/ oxytosis in neurons can be applied to ferroptosis in cancer cells (Figs. 12, 13). Indeed, we found that Adaptaquin, transglutaminase inhibitors, and Mithramycin all protect cancer cells from erastin similar to their protection in neuronal toxicity. However, HDAC inhibitors exacerbated erastin toxicity in cancer cells while promoting survival in neurons. Collectively, our data indicate that a combination of anticancer drugs may reverse the effect of single agents (as it is the case for erastin and Mithramycin), and that selectively targeting cancer cells while sparing neurons may be a more promising therapeutic approach.

It is important to note that sulfasalazine, which functions as an $\mathrm{X}_{\mathrm{c}}{ }^{-}$transport inhibitor like erastin, has been shown to not only inhibit glial-derived tumor (glioma) growth but also to inhibit neuronal excitotoxic death and seizures associated with these tumors (Chung et al.,
2005; Robert et al., 2015). Under these circumstances, sulfasalazine confers salutary effects on neurons by preventing the release of glutamate from gliomas. Indeed, glioma growth depends on glutamate release, and this may be a mechanism by which tumor cells remove neurons that compete for space and nutrients. These results suggest that erastin may actually prevent some toxicities to the CNS that are derived from tumors, rather than creating toxicities on its own.

However, several observations potentially reconcile our results with seminal studies from Sontheimer et al. First, they evaluated the effects of $X_{c}{ }^{-}$transport inhibition with only one drug concentration (sulfasalazine) where there is clear sensitivity of the glioma tumor to glutathione depletion but no effect on neurons or astrocytes. Indeed, studies here clearly demonstrate that cortical neurons are sensitive to $X_{c}{ }^{-}$transport inhibition with an $L_{50} 5$-fold higher than those required to kill $50 \%$ of the HT1080 cells. Second, they did not evaluate toxicity to peripheral neurons or central neurons directly, still leaving the question open whether $\mathrm{X}_{\mathrm{c}}{ }^{-}$inhibition systemically can lead to chemotherapy-induced neuropathy or chemo brain. Accordingly, apparent toxicity may occur under circumstances where drug concentrations used to kill tumor cells are higher and begin to approach the susceptibility of neurons. HDAC inhibitors in combination with erastin appear to be a viable strategy to minimize toxicity as they would reduce the concentration of erastin or sulfasalazine required for killing but would provide for neuroprotection from ferroptosis in their own right. 
In conclusion, cell death pathways in cancer cells and neurons exposed to glutathione depletion are similar as judged by the Fisher's tests. Our data suggest that HDAC inhibitors are promising therapeutic agents for combinatorial cancer chemotherapy to enhance chemotherapyinduced ferroptosis of tumors while inhibiting ferroptosis in neurons. The current study further identifies agents, some of which are known antitumor drugs, which would prevent erastin-induced toxicity in neurons (e.g., Adaptaquin, Mithramycin, transglutaminase inhibitors) and in cancer cells suggesting that these are not good combinatorial therapies to optimally kill tumor cells while preserving CNS and PNS neurons.

\section{References}

Banach M, Juranek JK, Zygulska AL (2017) Chemotherapy-induced neuropathies: a growing problem for patients and health care providers. Brain Behav 7:e00558. CrossRef Medline

Basso M, Berlin J, Xia L, Sleiman SF, Ko B, Haskew-Layton R, Kim E, Antonyak MA, Cerione RA, lismaa SE, Willis D, Cho S, Ratan RR (2012) Transglutaminase inhibition protects against oxidative stress-induced neuronal death downstream of pathological ERK activation. J Neurosci 32:6561-6569. CrossRef Medline

Berger SB, Bertin J, Gough PJ (2016) Life after death: RIP1 and RIP3 move beyond necroptosis. Cell Death Discov 2:16056. CrossRef Medline

Berger SB, Kasparcova V, Hoffman S, Swift B, Dare L, Schaeffer M, Capriotti C, Cook M, Finger J, Hughes-Earle A, Harris PA, Kaiser WJ, Mocarski ES, Bertin J, Gough PJ (2014) Cutting Edge: RIP1 kinase activity is dispensable for normal development but is a key regulator of inflammation in SHARPIN-deficient mice. $\mathrm{J}$ Immunol 192:5476-5480. CrossRef Medline

Bridges RJ, Natale NR, Patel SA (2012) System xc ${ }^{-}$cystine/glutamate antiporter: an update on molecular pharmacology and roles within the CNS. Br J Pharmacol 165:20-34. CrossRef Medline

Chatterjee S, Zaman K, Ryu H, Conforto A, Ratan RR (2001) Sequence-selective DNA binding drugs mithramycin A and chromomycin A3 are potent inhibitors of neuronal apoptosis induced by oxidative stress and DNA damage in cortical neurons. Ann Neurol 49:345-354. CrossRef Medline

Chung WJ, Lyons SA, Nelson GM, Hamza H, Gladson CL, Gillespie GY, Sontheimer H (2005) Inhibition of cystine uptake disrupts the growth of primary brain tumors. J Neurosci 25:7101-7110. CrossRef Medline

de Almagro MC, Goncharov T, Izrael-Tomasevic A, Duttler S, Kist M, Varfolomeev E, Wu X, Lee WP, Murray J, Webster JD, Yu K, Kirkpatrick DS, Newton K, Vucic D (2017) Coordinated ubiquitination and phosphorylation of RIP1 regulates necroptotic cell death. Cell Death Differ 24:26-37. CrossRef Medline

Degterev A, Huang Z, Boyce M, Li Y, Jagtap P, Mizushima N, Cuny GD, Mitchison TJ, Moskowitz MA, Yuan J (2005) Chemical inhibitor of nonapoptotic cell death with therapeutic potential for ischemic brain injury. Nat Chem Biol 1:112-119. CrossRef Medline

Dixon SJ, Patel DN, Welsch M, Skouta R, Lee ED, Hayano M, Thomas AG, Gleason CE, Tatonetti NP, Slusher BS, Stockwell BR (2014) Pharmacological inhibition of cystine-glutamate exchange induces endoplasmic reticulum stress and ferroptosis. eLife 3:e02523. CrossRef Medline

Dixon SJ, Lemberg KM, Lamprecht MR, Skouta R, Zaitsev EM, Gleason CE, Patel DN, Bauer AJ, Cantley AM, Yang WS, Morrison B 3rd, Stockwell BR (2012) Ferroptosis: an iron-dependent form of nonapoptotic cell death. Cell 149:1060-1072. CrossRef Medline

Ferrante RJ, Ryu H, Kubilus JK, D’Mello S, Sugars KL, Lee J, Lu P, Smith K, Browne S, Beal MF, Kristal BS, Stavrovskaya IG, Hewett S, Rubinsztein DC, Langley B, Ratan RR (2004) Chemotherapy for the brain: the antitumor antibiotic mithramycin prolongs survival in a mouse model of Huntington's disease. J Neurosci 24:1033510342. CrossRef

Galluzzi L, Vitale I, Aaronson SA, Abrams JM, Adam D, Agostinis P, Alnemri ES, Altucci L, Amelio I, Andrews DW, AnnicchiaricoPetruzzelli M, Antonov AV, Arama E, Baehrecke EH, Barlev NA, Bazan NG, Bernassola F, Bertrand MJ, Bianchi K, Blagosklonny $\mathrm{MV}$, et al. (2018) Molecular mechanisms of cell death: recommendations of the Nomenclature Committee on Cell Death 2018. Cell Death Differ 25:486-541. CrossRef Medline

Guo H, Omoto S, Harris PA, Finger JN, Bertin J, Gough PJ, Kaiser WJ, Mocarski ES (2015) Herpes simplex virus suppresses necroptosis in human cells. Cell Host Microbe 17:243-251. CrossRef Medline

Hou W, Xie Y, Song X, Sun X, Lotze MT, Zeh HJ 3rd, Kang R, Tang D (2016) Autophagy promotes ferroptosis by degradation of ferritin. Autophagy 12:1425-1428. CrossRef Medline

Karuppagounder SS, Alim I, Khim SJ, Bourassa MW, Sleiman SF, John R, Thinnes CC, Yeh TL, Demetriades M, Neitemeier S, Cruz D, Gazaryan I, Killilea DW, Morgenstern L, Xi G, Keep RF, Schallert T, Tappero RV, Zhong J, Cho S, et al. (2016) Therapeutic targeting of oxygen-sensing prolyl hydroxylases abrogates ATF4-dependent neuronal death and improves outcomes after brain hemorrhage in several rodent models. Sci Transl Med 8:328ra329. CrossRef Medline

Kerckhove N, Collin A, Condé S, Chaleteix C, Pezet D, Balayssac D (2017) Long-term effects, pathophysiological mechanisms, and risk factors of chemotherapy-induced peripheral neuropathies: a comprehensive literature review. Front Pharmacol 8:86. CrossRef Medline

Lange PS, Chavez JC, Pinto JT, Coppola G, Sun CW, Townes TM, Geschwind DH, Ratan RR (2008) ATF4 is an oxidative stressinducible, prodeath transcription factor in neurons in vitro and in vivo. J Exp Med 205:1227-1242. CrossRef Medline

Langley B, D'Annibale MA, Suh K, Ayoub I, Tolhurst A, Bastan B, Yang L, Ko B, Fisher M, Cho S, Beal MF, Ratan RR (2008) Pulse inhibition of histone deacetylases induces complete resistance to oxidative death in cortical neurons without toxicity and reveals a role for cytoplasmic p21waf1/cip1 in cell cycle-independent neuroprotection. J Neurosci 28:163-176. CrossRef Medline

Lewerenz J, Ates G, Methner A, Conrad M, Maher P (2018) Oxytosis/ ferroptosis-(Re-) emerging roles for oxidative stress-dependent non-apoptotic cell death in diseases of the central nervous system. Front Neurosci 12:214. CrossRef Medline

Lewerenz J, Hewett SJ, Huang Y, Lambros M, Gout PW, Kalivas PW, Massie A, Smolders I, Methner A, Pergande M, Smith SB, Ganapathy V, Maher P (2013) The cystine/glutamate antiporter system $x_{c}$ in health and disease: from molecular mechanisms to novel therapeutic opportunities. Antioxid Redox Signal 18:522-555. CrossRef Medline

Mandal P, Berger SB, Pillay S, Moriwaki K, Huang C, Guo H, Lich JD, Finger J, Kasparcova V, Votta B, Ouellette M, King BW, Wisnoski D, Lakdawala AS, DeMartino MP, Casillas LN, Haile PA, Sehon CA, Marquis RW, Upton J, et al. (2014) RIP3 induces apoptosis independent of pronecrotic kinase activity. Mol Cell 56:481-495. CrossRef Medline

McConoughey SJ, Basso M, Niatsetskaya ZV, Sleiman SF, Smirnova NA, Langley BC, Mahishi L, Cooper AJ, Antonyak MA, Cerione RA, Li B, Starkov A, Chaturvedi RK, Beal MF, Coppola G, Geschwind $\mathrm{DH}$, Ryu H, Xia L, lismaa SE, Pallos J, et al. (2010) Inhibition of transglutaminase 2 mitigates transcriptional dysregulation in models of Huntington disease. EMBO Mol Med 2:349-370. CrossRef Medline

Muller T, Dewitz C, Schmitz J, Schroder AS, Brasen JH, Stockwell BR, Murphy JM, Kunzendorf U, Krautwald S (2017) Necroptosis and ferroptosis are alternative cell death pathways that operate in acute kidney failure. Cell Mol Life Sci 74:3631-3645. CrossRef Medline

Murphy TH, Miyamoto M, Sastre A, Schnaar RL, Coyle JT (1989) Glutamate toxicity in a neuronal cell line involves inhibition of 
cystine transport leading to oxidative stress. Neuron 2:1547-1558. CrossRef Medline

Neitemeier S, Jelinek A, Laino V, Hoffmann L, Eisenbach I, Eying R, Ganjam GK, Dolga AM, Oppermann S, Culmsee C (2017) BID links ferroptosis to mitochondrial cell death pathways. Redox Biol 12: 558-570. CrossRef Medline

Newton K, Dugger DL, Maltzman A, Greve JM, Hedehus M, MartinMcNulty B, Carano RA, Cao TC, van Bruggen N, Bernstein L, Lee WP, Wu X, DeVoss J, Zhang J, Jeet S, Peng I, McKenzie BS, Roose-Girma M, Caplazi P, Diehl L, et al. (2016) RIPK3 deficiency or catalytically inactive RIPK1 provides greater benefit than MLKL deficiency in mouse models of inflammation and tissue injury. Cell Death Differ 23:1565-1576. CrossRef Medline

Pasquier B (2016) Autophagy inhibitors. Cell Mol Life Sci 73:9851001. CrossRef Medline

Ratan RR, Murphy TH, Baraban JM (1994a) Macromolecular synthesis inhibitors prevent oxidative stress-induced apoptosis in embryonic cortical neurons by shunting cysteine from protein synthesis to glutathione. J Neurosci 14:4385-4392. CrossRef Medline

Ratan RR, Murphy TH, Baraban JM (1994b) Oxidative stress induces apoptosis in embryonic cortical neurons. J Neurochem 62:376379. CrossRef Medline

Robert SM, Buckingham SC, Campbell SL, Robel S, Holt KT, Ogunrinu-Babarinde T, Warren PP, White DM, Reid MA, Eschbacher JM, Berens ME, Lahti AC, Nabors LB, Sontheimer H (2015) SLC7A11 expression is associated with seizures and predicts poor survival in patients with malignant glioma. Sci Transl Med 7:289ra286. CrossRef Medline

Ryu H, Lee J, Olofsson BA, Mwidau A, Dedeoglu A, Escudero M, Flemington E, Azizkhan-Clifford J, Ferrante RJ, Ratan RR (2003) Histone deacetylase inhibitors prevent oxidative neuronal death independent of expanded polyglutamine repeats via an Sp1dependent pathway. Proc Natl Acad Sci U S A 100:4281-4286. CrossRef Medline

Sleiman SF, Berlin J, Basso M, Karuppagounder SS, Rohr J, Ratan RR (2011a) Histone deacetylase inhibitors and mithramycin a impact a similar neuroprotective pathway at a crossroad between cancer and neurodegeneration. Pharmaceuticals 4:1183-1195. CrossRef Medline

Sleiman SF, Langley BC, Basso M, Berlin J, Xia L, Payappilly JB, Kharel MK, Guo H, Marsh JL, Thompson LM, Mahishi L, Ahuja P,
MacLellan WR, Geschwind DH, Coppola G, Rohr J, Ratan RR (2011b) Mithramycin is a gene-selective Sp1 inhibitor that identifies a biological intersection between cancer and neurodegeneration. J Neurosci 31:6858-6870. CrossRef Medline

Sleiman SF, Olson DE, Bourassa MW, Karuppagounder SS, Zhang YL, Gale J, Wagner FF, Basso M, Coppola G, Pinto JT, Holson EB, Ratan RR (2014) Hydroxamic acid-based histone deacetylase (HDAC) inhibitors can mediate neuroprotection independent of HDAC inhibition. J Neurosci 34:14328-14337. CrossRef Medline

Sun L, Wang H, Wang Z, He S, Chen S, Liao D, Wang L, Yan J, Liu W, Lei X, Wang X (2012) Mixed lineage kinase domain-like protein mediates necrosis signaling downstream of RIP3 kinase. Cell 148: 213-227. CrossRef Medline

Tan S, Zhou F, Nielsen VG, Wang Z, Gladson CL, Parks DA (1998) Sustained hypoxia-ischemia results in reactive nitrogen and oxygen species production and injury in the premature fetal rabbit brain. J Neuropathol Exp Neurol 57:544-553. CrossRef Medline

Torii S, Shintoku R, Kubota C, Yaegashi M, Torii R, Sasaki M, Suzuki T, Mori M, Yoshimoto Y, Takeuchi T, Yamada K (2016) An essential role for functional lysosomes in ferroptosis of cancer cells. Biochem J 473:769-777. CrossRef Medline

Vitali M, Ripamonti Cl, Roila F, Proto C, Signorelli D, Imbimbo M, Corrao G, Brissa A, Rosaria G, de Braud F, Garassino MC, Lo Russo G (2017) Cognitive impairment and chemotherapy: a brief overview. Crit Rev Oncol Hematol 118:7-14. CrossRef Medline

Yang WS, Stockwell BR (2016) Ferroptosis: death by lipid peroxidation. Trends Cell Biol 26:165-176. CrossRef Medline

Yang WS, SriRamaratnam R, Welsch ME, Shimada K, Skouta R, Viswanathan VS, Cheah JH, Clemons PA, Shamji AF, Clish CB, Brown LM, Girotti AW, Cornish VW, Schreiber SL, Stockwell BR (2014) Regulation of ferroptotic cancer cell death by GPX4. Cell 156:317-331. CrossRef Medline

Yu Y, Xie Y, Cao L, Yang L, Yang M, Lotze MT, Zeh HJ, Kang R, Tang D (2015) The ferroptosis inducer erastin enhances sensitivity of acute myeloid leukemia cells to chemotherapeutic agents. Mol Cell Oncol 2:e1054549. CrossRef Medline

Zille M, Karuppagounder SS, Chen Y, Gough PJ, Bertin J, Finger J, Milner TA, Jonas EA, Ratan RR (2017) Neuronal Death after hemorrhagic stroke in vitro and in vivo shares features of ferroptosis and necroptosis. Stroke 48:1033-1043. CrossRef Medline 